\begin{tabular}{|l|c|c|c|c|}
\hline $\begin{array}{l}\text { Cuadernos de Investigación Geográfica } \\
\text { Geographical Research Letters }\end{array}$ & 2020 & $N^{\circ} 46(1)$ & pp. 187-222 & eISSN 1697-9540 \\
\hline
\end{tabular}

\title{
FROZEN GROUND AND SNOW COVER MONITORING IN LIVINGSTON AND DECEPTION ISLANDS, ANTARCTICA: PRELIMINARY RESULTS OF THE 2015-2019 PERMASNOW PROJECT
}

\author{
M.A. DE PABLO ${ }^{1 *}$, J.J. JIMÉNEZ ${ }^{2}$, M. RAMOS ${ }^{2}$, M. PRIETO ${ }^{3}$, \\ A. MOLINA ${ }^{4}$, G. VIEIRA ${ }^{5}$, M.A. HIDALGO ${ }^{2}$, S. FERNÁNDEZ $^{6}$, \\ C. RECONDO ${ }^{7}$, J.F. CALLEJA ${ }^{8}$, J.J. PEON ${ }^{7}$, A. CORBEA-PÉREZ ${ }^{7}$, \\ C.N. MAIOR ${ }^{1}$, M. MORALES ${ }^{1}$, C. MORA $^{5}$ \\ ${ }^{1}$ Department of Geology, Geography and Environment, University of Alcalá, Madrid, Spain. \\ ${ }^{2}$ Department of Physics and Mathematics, University of Alcalá, Madrid, Spain. \\ ${ }^{3}$ Department of Automatics, University of Alcalá, Madrid, Spain. \\ ${ }^{4}$ Department of Planetary Geology, Centro de Astrobiología (CSIC-INTA), Madrid, Spain. \\ ${ }^{5}$ Center of Geographic Studies/IGOT, Universidade de Lisboa, Lisbon, Portugal. \\ ${ }^{6}$ Department of Geology, University of Oviedo, Oviedo, Spain.
}

${ }^{7}$ Department of Mining Exploitation and Prospecting, University of Oviedo, Oviedo, Spain.

${ }^{8}$ Department of Physics, University of Oviedo, Oviedo, Spain.

\begin{abstract}
Since 2006, our research team has been establishing in the islands of Livingston and Deception, (South Shetland archipelago, Antarctica) several monitoring stations of the active layer thickness within the international network Circumpolar Active Layer Monitoring (CALM), and the ground thermal regime for the Ground Terrestrial Network-Permafrost (GTN-P). Both networks were developed within the International Permafrost Association (IPA). In the GTN-P stations, in addition to the temperature of the air, soil, and terrain at different depths, the snow thickness is also monitored by snow poles. Since 2006, a delay in the disappearance of the snow layer has been observed, which could explain the variations we observed in the active layer thickness and permafrost temperatures. Therefore, in late 2015 our research group started the PERMASNOW project (2015-2019) to pay attention to the effect of snow cover on ground thermal This
\end{abstract}


project had two different ways to study the snow cover. On the first hand, in early 2017 we deployed new instrumentation, including new time lapse cameras, snow poles with high number of sensors and a complete and complex set of instruments and sensors to configure a snow pack analyzer station providing 32 environmental and snow parameters. We used the data acquired along 2017 and 2018 years with the new instruments, together with the available from all our already existing sensors, to study in detail the snow cover. On the other hand, remote sensing data were used to try to map the snow cover, not only at our monitoring stations but the entire islands in order to map and study the snow cover distribution, as well as to start the way for future permafrost mapping in the entire islands. MODIS-derived surface temperatures and albedo products were used to detect the snow cover and to test the surface temperature. Since cloud presence limited the acquisition of valid observations of MODIS sensor, we also analyzed Terrasar X data to overcome this limitation. Remote sensing data validation required the acquirement of in situ ground-true data, consisting on data from our permanent instruments, as well as ad hoc measurements in the field (snow cover mapping, snow pits, albedo characterization, etc.). Although the project is finished, the data analysis is still ongoing. We present here the different research tasks we are developing as well as the most important results we already obtained about the snow cover. These results confirm how the snow cover duration has been changing in the last years, affecting the ground thermal behavior.

Monitorización de los suelos congelados y la cubierta de nieve en las islas Livingston and Deception, Antártida: Resultados preliminares del proyecto PERMASNOW

RESUMEN. Desde el año 2006, nuestro equipo de investigación ha ido estableciendo, en las islas Livingston y Decepción, en el archipiélago de las Shetland del Sur, Antártida, varias estaciones de monitorización del espesor de la capa activa, dentro de la red internacional Circumpolar Active Layer Monitoring (CALM), y del régimen térmico de los suelos para la red Ground Terrestrial Network-Permafrost (GTN-P). Ambas redes resultan de grupos de trabajo de la Asociación Internacional del Permafrost (IPA). En las estaciones GTN-P, además de la temperatura del aire, suelo, y terreno a distintas profundidades, se monitoriza, mediante termonivómetros, el espesor de la cubierta nival. Desde el año 2006 se ha ido observado un retraso en la desaparición de la capa de nieve, lo que podría explicar las variaciones que estábamos midiendo en el espesor y temperatura de la capa activa y el permafrost. Por ello, a finales de 2015 iniciamos el proyecto PERMASNOW (2015-2019) para estudiar el efecto de la capa de nieve en el régimen térmico del suelo. Este proyecto incluía dos vías para el estudio de la nieve. Por un lado, a principios de 2017 se desplegaron nuevos instrumentos en nuestras zonas de estudio, incluyendo cámaras fotográficas automáticas, termonivómetros con mayor número de sensores y un conjunto de sensores que configuran una estación para la observación de 3 variables atmosféricas y de la cubierta nival. Utilizamos los datos adquiridos a lo largo de los años 2017 y 2018 por estos nuevos instrumentos y sensores, 
junto con los de los demás instrumentos previamente existentes en nuestras estaciones GTN-P, para estudiar en detalle la cubierta de nieve. Por otro lado, se utilizó la teledetección para tratar de cartografiar dicha cubierta nival, no sólo en nuestras estaciones, sino también en la totalidad de estas islas con el fin conocer la distribución de la cubierta de nieve, y abrir así la vía a la futura cartografía de la distribución del permafrost en las mismas. Se utilizaron temperaturas superficiales y albedo derivadas del instrumento MODIS para detectar la cubierta de nieve y para analizar la temperatura superficial. Por otro lado, debido a la limitación de los sensores ópticos en esta región nubosa, también se utilizaron datos de radar Terrasar X. Para el análisis de datos de teledetección se tomaron datos in situ (verdad terreno) como cartografía de la capa nival, catas de nieve, mediciones de albedo, etc. Aunque el proyecto está terminado, el análisis de datos todavía está en curso. Aquí presentamos las diferentes tareas de investigación que estamos desarrollando, así como los resultados más importantes que ya hemos obtenido sobre la cubierta de nieve, que confirman cómo la duración de la cubierta de nieve ha ido cambiando en los últimos años, y está afectando al comportamiento térmico del suelo.

Keywords: Permafrost, active layer, snow cover, Antarctica, remote sensing.

Palabras clave: Permafrost, capa activa, nieve, Antártida, teledetección.

Received: 30 September 2019

Accepted: 6 January 2020

* Corresponding author: Prof. Dr. Miguel Ángel de Pablo, Unidad de Geología, Departamento de Geología, Geografía y Medio Ambiente, Edificio de Ciencias, Campus Científico-Tecnológico, Universidad de Alcalá, Ctra. A-II, km 33,600, 28805 Alcalá de Henares, Madrid, Spain. E-mail address: miguelangel.depablo@uah.es

\section{Introduction}

Permafrost is one of the key components of the Cryosphere, as identified by the International Panel on Climate Change (e.g., IPPC, 2013), and therefore, a fundamental element for the understanding of the present global warming, as well as the future changes in the atmosphere, hydrosphere, geosphere and the terrestrial and marine ecosystems (e.g., IPPC, 2018). Then, the understanding of permafrost thermal state and distribution is a must at global scale. Despite the complexity of its monitoring, Circumpolar Active Layer Monitoring (CALM; e.g., Brown et al., 2000; Nelson et al., 2004) and Ground Terrestrial Network-Permafrost (GTN-P; e.g., Biskaborn et al., 2015) international networks are focused on studying the evolution of the active layer thickness and permafrost thermal regimen, respectively. Each network defines a protocol for the establishment of standard stations where to monitor the active layer thickness every 10 meters by mechanical probing in a 100x100 m grid (CALM sites), and the instruments to monitor the air, surface and ground thermal regime, as well as to approach snow thickness by snow poles (GTN-P stations). 
Changes on the permafrost temperature and the increase of the active layer thickness is already a fact, as reported from the data acquired at different CALM and GTN-P monitoring sites locates at both Arctic and Antarctic regions since early 80s (e.g., Brown et al., 2000) and confirmed in recent reports (e.g., Hrbáček et al., 2018; Abramov et al., 2019).

Meanwhile in the Arctic there is a long history of permafrost and active layer monitoring, in Antarctica, only in the last 2 decades its monitoring started to be systematical (Brown et al., 2000), but still few monitoring sites exist in comparison with the Arctic (e.g., Vieira et al., 2010). In spite of the small number and relatively recent stations, variations on permafrost and active layer dynamics has been already reported in Antarctic permafrost (Bockheim et al., 2013; Vieira et al., 2010; Hrbáček et al., 2018; Biskaborn et al., 2019), especially in the western Antarctic Peninsula area (e.g., Vieira et al., 2010; Ramos et al., 2016; de Pablo et al., 2017a, 2017b), in relation to the shifting climate conditions over the last decades occurring in this Antarctic sector (Oliva et al., 2017a, 2017b; Turner et al., 2005, 2016). Although the air temperature increase seems to be a direct cause of the permafrost warming registered in Antarctica (Biskaborn et al., 2019), it is well known than snow cover is also an important factor that could contribute to change the permafrost and active layer thermal regime (see Gooddrich, 1982 and Zhang, 2005 for a review), as it has been reported recently in the Antarctic peninsula area (e.g., Ramos et al., 2016; de Pablo et al., 2017; Oliva et al., 2017a; Hrbáček et al., 2016a, 2016b; Hrbáček and Huxa, 2019).

In this scenario, to continue monitoring the permafrost in Antarctica should be considered a priority research topic, as well as the study of the processes that could affect its thermal regime, such as the snow cover spatio-temporal evolution. Our research team has been monitoring active layer thickness, air, surface and ground temperatures, and approaching the snow thickness in different CALM and GTN-P stations in Livingston and Deception Islands since 2006 (de Pablo et al., 2016). Due to the cited relevance of the snow cover, in early 2015 we started a research project (PERMASNOW) completely focused on the snow cover monitoring to characterize in detail the snow cover properties and its evolution since 2017. The objective of this project was to constrain the effect of the snow on the thermal regime of permafrost and active layer (de Pablo et al., 2016). We present here the most important tasks we developed on PERMASNOW project to monitor the snow cover, its properties, and evolution. Most of these investigations are still ongoing, but we show here the most important preliminary results by the end of the project regarding to snow cover behavior and its relation to permafrost evolution in Deception and Livingston Islands.

\section{Monitoring sites and new instrumentation}

\subsection{Monitoring sites}

There are 9 monitoring sites in Deception and Livingston islands (Fig. 1) under direct responsibility of the Alcalá University research team, and the close collaboration of our partner team from the University of Lisbon, Portugal (see de Pablo et al., 2016 for a review of the history of these monitoring sites and the international cooperation). 


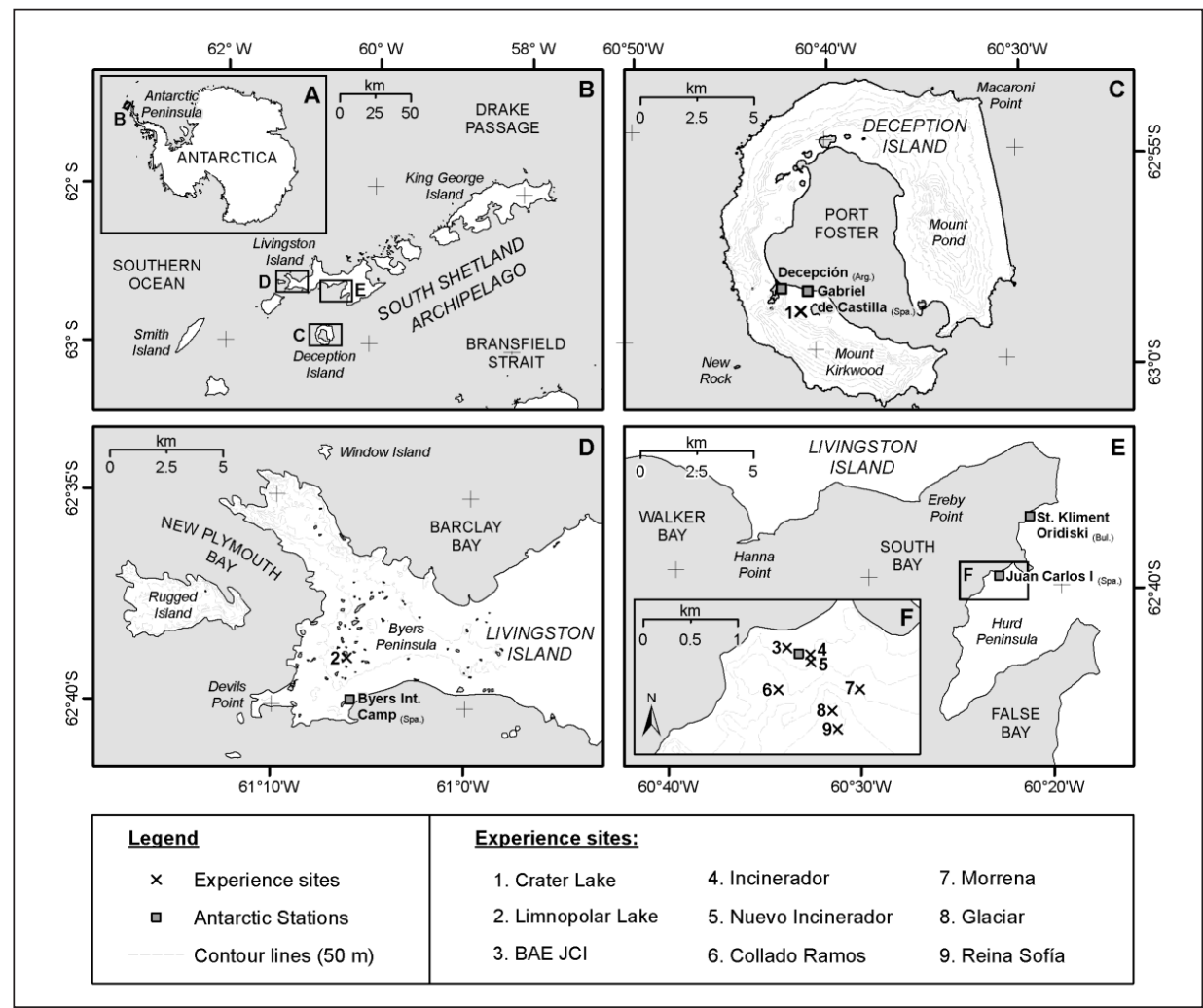

Figure 1. Location map of the monitoring sites in Antarctica (A) for the CALM and GTN-P international networks for active layer thickness and ground temperatures, respectively. Sites are located at South Shetland Archipelago (B): Deception island (B) and both Byers Peninsula $(D)$ and Hurd Peninsula ( $E$ and $F$ ) in Livingston island. (modified from de Pablo et al., 2016).

The monitoring site in Deception island (Table 1), Crater Lake (CL), includes the Crater Lake CALM site -A16-, and 6 GTN-P sites (85 m a.s.1.), meanwhile in Livingston island the monitoring sites are in opposite locations of the island. In Byers peninsula the monitoring site, Limnopolar Lake, includes the Limnopolar Lake CALM site -A25and two GTN-P sites (80 m a.s.1.). In Hurd peninsula, 7 GTN-P monitoring sites are altitudinally distributed from the coast (10 m a.s.l.) to the summit of Reina Sofía peak (285 m a.s.1.) (de Pablo et al., 2016) (Table 1). These stations allow us to monitor active layer and permafrost in areas of similar elevation but different lithology, as well as sites with comparable lithological characteristics, but different elevations (de Pablo et al., 2019a), and not identical weather conditions (Bañón et al., 2015). This allow us to consider these factors. A brief overview of the instrumentation deployed in our stations since 2006 in our CALM and GTN-P monitoring sites (Table 1) was already provided in de Pablo et al. (2016), showing that they monitor air, ground surface and ground temperatures as well as snow thickness using snow poles. 
De Pablo et al.

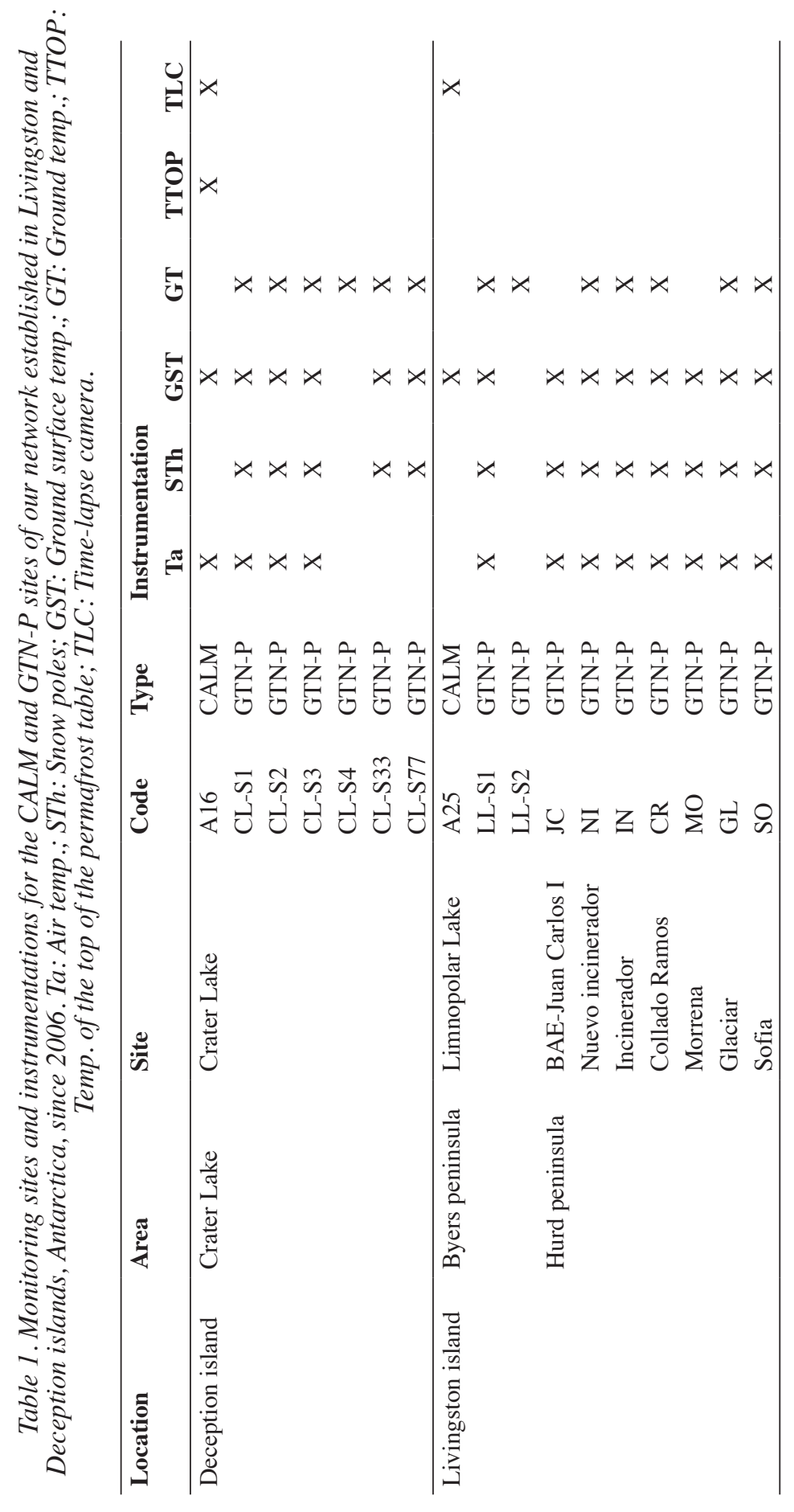




\subsection{New monitoring instruments}

The focus on the snow cover of PERMASNOW project required the installation (or the replacement) of new instruments in our monitoring sites. We focused on the Limnopolar Lake and Crater Lake CALM sites (on Livingston and Deception Islands, respectively) because more of our instruments are concentrated there, monitoring both ground temperatures and active layer thickness. We added then 3 new snow poles on each CALM site to approximate the snow thickness by the classical method, consisting on assume that all the sensors register similar temperatures when they are snow free, but show evident differences on acquired temperatures each time one of the sensors is covered by the snow (Lewkowicz, 2008). By this method it is able to approach the snow thickness such as the mean height among two consecutive sensors in the array when the lower one (Snow covered) has a temperature behavior different than the upper one (snow free). The 3 new snow poles we installed in each CALM Site allows more accurate snow thickness than our already existing snow poles because we mounted 15 temperature sensors (and not only 7) at 2.5, 5, 10, 20, 30, 40, 50, 60, $70,80,90,100,120,140$, and $160 \mathrm{~cm}$ above the ground surface. The poles have been installed in a diagonal distribution inside the CALM sites grid, following the snow cover retreatment front that we observed when analyzing the time-lapse automatic cameras images. We also mounted an additional snow pole with similar distribution of sensors close to the new snow pack analyzer (SPA) station in Crater Lake CALM site, to compare and correct partially the rough approach of the snow cover derived from the snow poles with the high-resolution snow cover depth hourly measurements done by the ultrasound sensor mounted in a new SPA station described below.

The data derived from these new snow poles, and all the existing ones, will help to interpolate a daily snow cover map of the CALM sites. Moreover, we will derive snow onset, offset and snow cover duration, that will be analyzed together with the ground surface temperatures (GST) measured in many grid noded along the year, as well as the active layer thickness, measured once a year during the thaw season by mechanical probing.

These tasks are supported by the images acquired by automatic time-lapse cameras installed in each CALM site. Besides the already existing cameras, we installed new ones close to the grid, allowing to capture images of the whole CALM sites as well as the surroundings (providing context views) and the sky (providing a glimpse of the daily weather). Compared to already existing cameras, the new Campbell Scientific C5MPX cameras (5 MPixels) provides slightly higher resolution. There cameras are closer to the CALM sites, allowing to observe most of the instruments and the limits of each monitoring site, marked with 2 meters high stakes with red and white $10 \mathrm{~cm}$ high banding. All cameras have been setting to take 3 pictures per day at local solar noon (13, 14 , and 15 h UTC).

Finally, a SPA station has been installed in the edge of the Crater Lake CALM site (Fig. 2), the most important improvement on the instrumentation. SPA is developed by Sommer Messtechnik and includes several sensors to monitor environmental variables, snow cover properties, and GST (see section 5). SPA includes a CNR1 net 
radiometer with up and down pyranometers and pyrgeometers by Campbell Scientific. Data is acquired hourly and stored into MDL-5 datalogger by Sommer Messtechnik, with $2 \mathrm{Mb}$ of memory, allowing more than 2 years of continuous monitoring of all the variables. This station is powered by a $12 \mathrm{~V}$ battery charged with a $12 \mathrm{~V}$ solar panel (Fig. 2). SPA station is the first one of this kind installed in Antarctica to monitor snow cover properties and is the main instrumental contribution of PERMASNOW project. This station was continuously working along the last 2 years providing better resolution and realistic snow depth measurements, together with other environment, thermal and snow properties parameters (32) (Table 2). All these data allow to interpret the thermal behavior measured inside our monitoring network boreholes in Livingston and Deception Islands.

Table 2. Parameters (and units) measured by the different instruments that integrate the Snow Pack Analyzer station in Deception Island, Antarctica (Lengths in cm above the ground).

\begin{tabular}{lll}
\hline Environmental & Thermal & Properties \\
\hline Date @ Time & Device temperature $\left({ }^{\circ} \mathrm{C}\right)$ & Ice content pack $(\%)$ \\
Air temperature $\left({ }^{\circ} \mathrm{C}\right)$ & Surface temperature $\left({ }^{\circ} \mathrm{C}\right)$ & Water content pack $(\%)$ \\
Air humidity $(\%)$ & Ground Surface temperature $\left({ }^{\circ} \mathrm{C}\right)$ & Density pack $\left(\mathrm{kg} / \mathrm{m}^{3}\right)$ \\
Pyranometer Up $\left(\mathrm{W} / \mathrm{m}^{2}\right)$ & Temperature $10 \mathrm{~cm}\left({ }^{\circ} \mathrm{C}\right)$ & SWE pack $(\mathrm{mm})$ \\
Pyranometer Down $\left(\mathrm{W} / \mathrm{m}^{2}\right)$ & Temperature $20 \mathrm{~cm}\left({ }^{\circ} \mathrm{C}\right)$ & Ice content $10 \mathrm{~cm}(\%)$ \\
Pyrgeometer Up $\left(\mathrm{W} / \mathrm{m}^{2}\right)$ & Temperature $40 \mathrm{~cm}\left({ }^{\circ} \mathrm{C}\right)$ & Water content $10 \mathrm{~cm}(\%)$ \\
Pyrgeometer Down $\left(\mathrm{W} / \mathrm{m}^{2}\right)$ & Temperature $80 \mathrm{~cm}\left({ }^{\circ} \mathrm{C}\right)$ & Density $10 \mathrm{~cm}\left(\mathrm{~kg} / \mathrm{m}^{3}\right)$ \\
& Temperature $100 \mathrm{~cm}\left({ }^{\circ} \mathrm{C}\right)$ & SWE $10 \mathrm{~cm}(\mathrm{~mm})$ \\
& & Ice content $30 \mathrm{~cm}(\%)$ \\
& & Water content $30 \mathrm{~cm}(\%)$ \\
& & Density $30 \mathrm{~cm}\left(\mathrm{~kg} / \mathrm{m}^{3}\right)$ \\
& & SWE $30 \mathrm{~cm}(\mathrm{~mm})$ \\
& & Ice content $50 \mathrm{~cm}(\%)$ \\
& & Water content $50 \mathrm{~cm}(\%)$ \\
& & Density $50 \mathrm{~cm}\left(\mathrm{~kg} / \mathrm{m}^{3}\right)$ \\
& SWE $50 \mathrm{~cm}(\mathrm{~mm})$ \\
& Snow weight $\left(\mathrm{kg} / \mathrm{m}^{2}\right)$ \\
& Snow Depth $(\mathrm{cm})$ \\
\hline
\end{tabular}




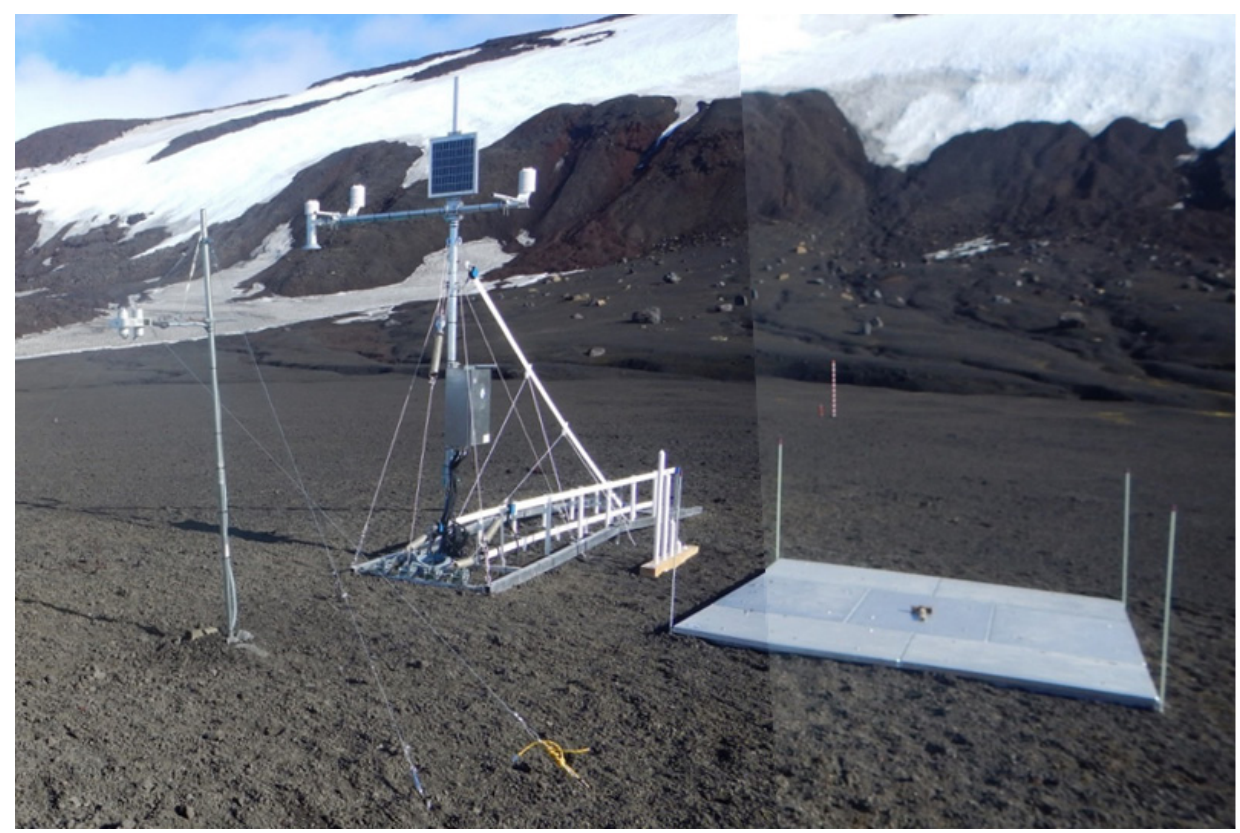

Figure 2. Snow Pack Analyzer station installed in Crater Lake CALM site in 2016 to monitor 32 environmental and snow variables.

\subsection{Field measurements}

To characterize the ground surface and snow cover, different properties were measured during the Antarctic field campaigns developed between early January and early March in 2017, 2018 and 2019.

The effects of the snow cover on the ground temperatures depends on snow cover thickness and its properties. However, we also consider ground lithology, granulometry, water content, and thermal conductivity. We sampled rock and sediment to (1) develop granulometry analysis (on sediments), and (2) laboratory measurements of frozen/ unfrozen thermal conductivity (on both rocks and sediments). We also measure in situ in all our monitoring sites the volumetric water content using a Campbell Scientific Hydrosense II device with CS659 $12 \mathrm{~cm}$ long rods and thermal conductivity using a Thermtest instruments TSL-100 device with a $50 \mathrm{~mm}$ long sensor nail.

We mapped the snow cover in the Crater Lake CALM site on different days directly on the field during each season, including the dates matching with RADAR TerrasarX images to allow image interpretation (Section 8.3.). We mapped the snow patches shape and its depth (when more than $10 \mathrm{~cm}$ ) inside the CALM site. We used a Snowmetrics co. snow depth probe together with our own instrument, the Snow Pack Analyzer Sounder (see Section 8).

We also observed the snow pits evolution in different patches, with a similar purpose than the snow cover maps using a classical equipment for snow pits (ProSnow 
Kit III by Snowmetrics co.). We develop more than 25 snow pits to derive temperature variability along its profile, snow grain size and shape, snow layers depth, hardness, density and snow water equivalent (SWE) for each layer following the common methods (e.g., Singh, 2011; NASA, nad). Snow pits were also measured in GTN-P monitoring sites to correlate snow cover properties and MODIS satellite images derived albedo.

We characterize albedo in ground surfaces and snow covers using 2 pyranometers LP Pyra $032^{\text {nd }}$ class connected to each HD2102.2 portable luxmeter datalogger from Deltha Ohm. They were installed in a pole end, pointing up and down, tracking different profiles of raw surfaces or snow patches (clean and debris covered, recent and old), glaciers, and water surfaces (sea) meanwhile we transported the pole horizontally by walking, or travelling on a snowmobile, or in a pneumatic boat, respectively. The measurements in those surfaces under various weather conditions are used as ground-true information for MODIS-derived albedo products. There images will allow the production of regional snow cover maps as an input for the regional mapping of permafrost distribution.

A FLIR E60 handheld thermal camera was also used during the campaigns to take oblique panoramic pictures of the CALM sites. This additional measurement on ground surface temperature is used to test the relation to ground surface temperature measured in the grid (de Pablo et al., 2019d). If the results are compelling, we plan to install timelapse thermal cameras in our monitoring sites.

\section{Snow cover mapping}

The images provided by the different automatic time-lapse cameras have been analyzed to obtain a daily schedule of the snow cover during the year (Fig. 3). By visual analysis we establish a snow coverage of $100 \%,>50 \%,<50 \%$, patches of snow, superficial snowfall, or snow free CALM Site surface. Days with reduced visibility (fog, snow-covered viewfinder, or ice-covered viewfinder or without data) are also included in the schedule. The analysis of the time-lapse images provides a global idea of the snow cover evolution in the monitoring site, a general evaluation of the snow cover onset, offset, and duration. Yearly evolution of these results versus the air and ground temperatures behavior and active layer thickness can reveal the relation between them.

A similar visual analysis of the snow cover distribution in the CALM site on Deception island was performed using a CC640 time-lapse camera (Fernández et al., 2017). We defined 6 different types of surfaces accordingly to their snow cover (Fig. 4) observing the image color A qualitative variable that takes values between 1 and 6 was defined to classify the thickness and continuity of the snow layer on the CALM site. These six values ( 1 without snow; 2 and 3 correspond to images with discontinuous snow cover; 4 and 5 represent completely covered images but with a shallow snow layer; 6 covered by continuous and deep snow layer) were useful for approaching a visual classification of the images based on the amount of snow present in the CALM site. All pictures were classify using this new variable and the whole dataset of available images were classified, obtaining a relation of days when each type of coverage was present 


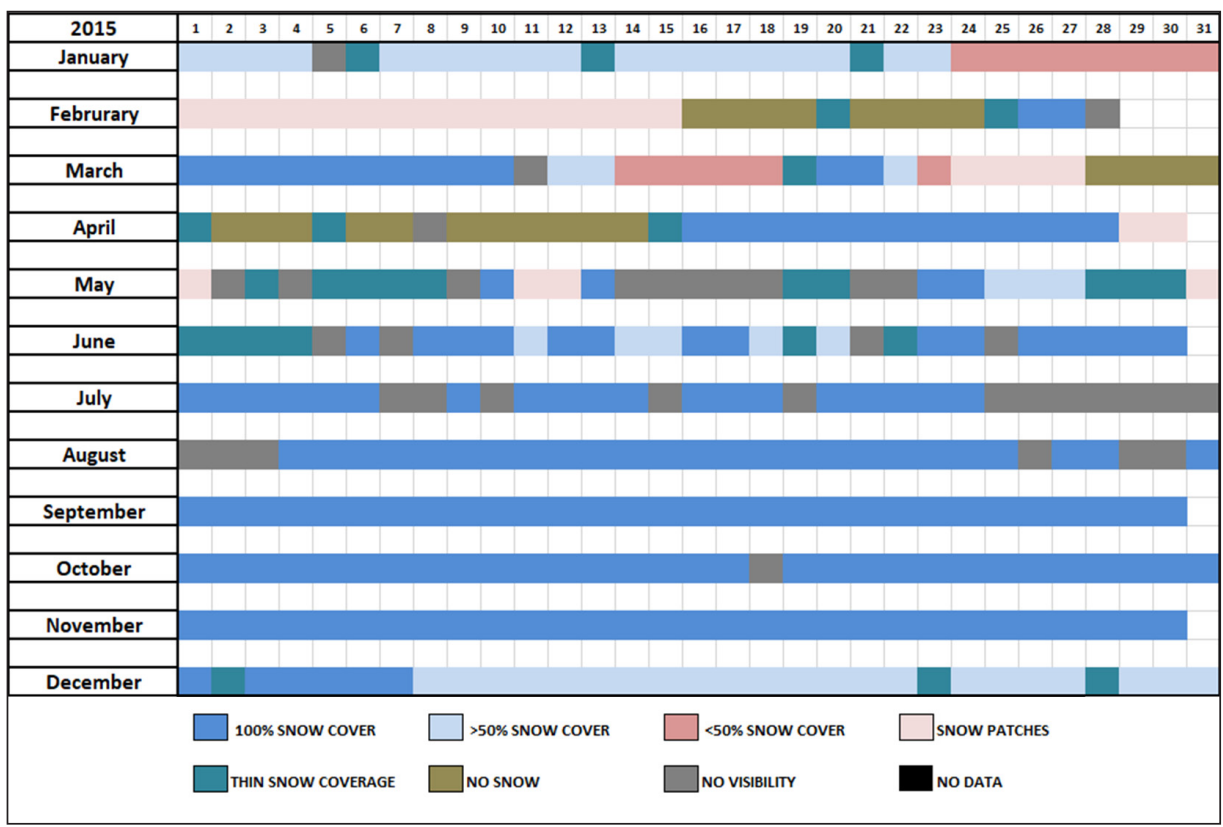

Figure 3. Example of the snow coverage study based on visual analysis of the photographic. The records correspond to 2015 in Crater Lake CALM site, on Deception island.

1
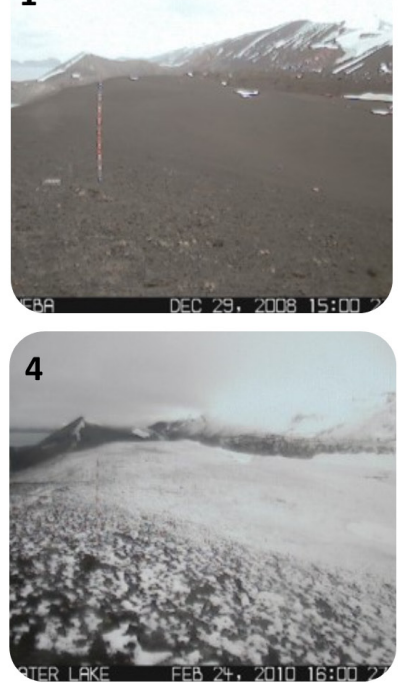

2
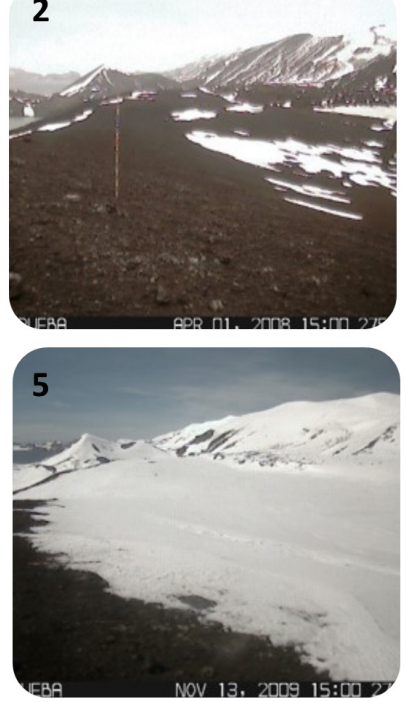

3
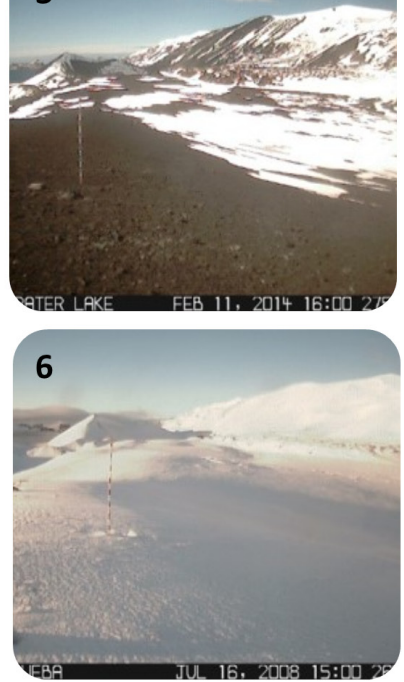

Figure 4. Types of coverage as seen on the time-lapse camera images acquired of the Crater Lake CALM site on Deception island, based on the image color classification. 
in the study surface (Table 3). The results do not show a clear evolution pattern for any coverage type during the study period. A reduction of the snow-free days along the 2008-2015 period is however evident, as well as an important increase on the days with intermedium coverages. The number of days with full snow coverage remains similar for the studied period.

Table 3. Number of days with the different types of coverage in the study area in Deception island, and air and TTOP mean temperatures $\left({ }^{\circ} \mathrm{C}\right)$ for the entire study period for the days under the distinct types of coverage.

\begin{tabular}{clllllll}
\hline Year & 1 & 2 & 3 & 4 & 5 & 6 & Total \\
\hline 2008 & 23 & 40 & 29 & 14 & 69 & 136 & 311 \\
2009 & 70 & 4 & 70 & 3 & 117 & 99 & 363 \\
2010 & 8 & 51 & 84 & 31 & 180 & 11 & 365 \\
2011 & 53 & 12 & 92 & 18 & 131 & 59 & 365 \\
2012 & 48 & 27 & 74 & 4 & 74 & 137 & 365 \\
2013 & 55 & 11 & 82 & 6 & 174 & 35 & 365 \\
2014 & 12 & 18 & 84 & 9 & 18 & 224 & 365 \\
2015 & 9 & 50 & 112 & 0 & 137 & 57 & 365 \\
\hline Air & 1.03 & 0.63 & -1.90 & -2.20 & -4.29 & -4.72 & \\
TTOP & -0.10 & -0.70 & -1.11 & -1.48 & -1.89 & -2.61 & \\
\hline
\end{tabular}

Air temperature and top of the permafrost table temperature (TTOP) data from the shallow boreholes distributed in the CALM site (Table 1) were also analyzed to determine a possible relationship among the shallow ground temperatures and each type of coverage classified. The yearly maximum, mean, and minimum data for each dataset shows an indisputable relationship for each coverage type and the air and shallow ground surface temperatures: snow-free coverage (type 1) is related to higher temperatures, while full snow coverage implies lower temperatures with lower variability on the TTOP. This is due to the expected thermal signal attenuation of the ground, partially attributed to the snow coverage evolution on this site (Ramos et al., 2016). This research provides an innovative qualitative approach to the snow cover effect on ground surface temperatures.

Using the new improved resolution cameras (5 Mpixels) installed in 2017, an application of automatic georeferencing of the images obtained during the hours of maximum insolation (14:00, 15:00 and 16:00 UTC) has been developed. Given the very small study area and its relatively flat topography, a georeferencing matrix has been created by visual identification of 11 control points per image inside the CALM site whose coordinates were obtained by a Differential Global Position System (GPS-D) device. By means of a spline transformation, orthorectified images (RMS less than $3.3 \times 10^{-4}$ degrees) 
are generated which are subsequently processed to assess the statistical distribution of the digital signal levels (DN). Then, by means of a slice treatment (equal interval) and based on the mean standard deviation obtained, a parametric surface classification is performed (Jiménez et al., 2019b). It is a deep simplification, not evaluating albedo, of the model developed by Corripio et al. (2004) and implemented on the PRACTISE software (Härer et al., 2013); although in this case the development has been carried out on a Python language script executed over ArcGIS 10.3.

In the first version of the product, systematic errors of the acquisition system have not been considered (optical distortion introduced by camera lenses or slight movements induced by the wind), since the main objective is the study of seasonal transitions of snow cover and the number of days of its persistence on the ground, rather than the exact delimitation of snow patches and their extension on the surface of the CALM site. The all year round time-lapse camera is considered here like a complementary source of information to the in-situ sensors installed and to the Radar remote sensing acquisitions performed during the study. The products obtained are: (1) snow cover maps (snow/not snow) (Fig. 5); (2) a database of area corresponding to each type of coverage (approach); and (3) a correspondence database of that daily snow coverage in each node of the CALM site.

These data open new fields of research of the snow cover effect on the ground surface temperatures and active layer thickness. The resulting database of daily snow cover for each node of the CALM site grid allow to derive snow cover onset, offset and duration for all the individual nodes, for each year. These data could be compared to the measured active layer thickness (de Pablo et al., 2019d) and to the ground surface temperature data monitored in 36 of the 121 CALM nodes, regularly distributed in the $100 \times 100 \mathrm{~m}$ grid. The latter can show the effect of the snow cover parameters on the thermal signal and to

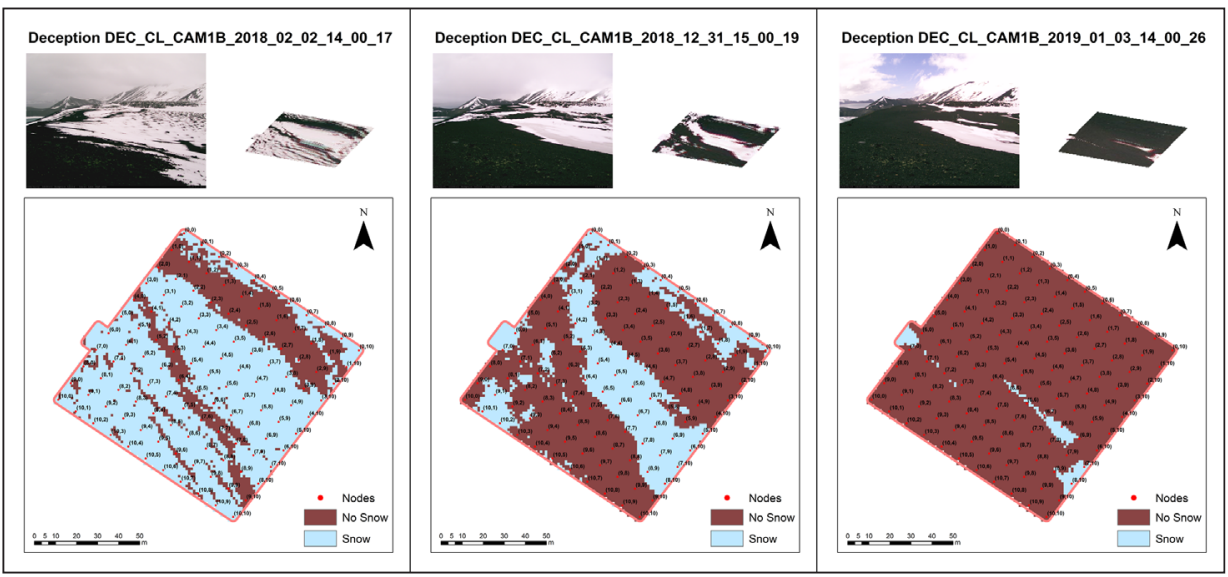

Figure 5. Examples of snow cover maps obtained through automated processes at the Crater

Lake CALM site on Deception Island. The photographic record is included in the upper left corner as obtained by the camera, on its right the orthorectified image of the CALM plot and in the lower part the map of classified surfaces obtained after the treatments. 
confirm the effect of thermal stabilization generated by the snow cover. This distributed analysis will be a new and important contribution of the PERMASNOW project to the understanding of the snow cover effect on the behavior we observed in the active layer thickness and GST (Ramos et al., 2016; de Pablo et al., 2017).

\section{Snow cover thickness and properties}

The snow measuring poles installed in different sites of Deception and Livingston Islands (see Section 2) have acquired snow thickness data continuously during the 20062018 period (Fig. 6). There are some gaps on the datasets due to the loss of full poles caused by the strong winter winds or malfunction of the sensors caused by the harsh meteorological conditions. However, the time coverage still allows us to describe snow evolution on these sites. Besides, this extensive register permit to infer local and regional trends, as they are located at different orientations and heights. Despite the low height resolution and the underestimation of the thickness of this method, results are consistent. Interannual variation trends are repeated on most of the sites, with a similar height of snow cover during time each year.

Winds have a great role in the snow pack prevalence, and the more exposed sites displays systematically shallower snow covers. This can be observed in mountain peaks (as on SO site, Table 1) or hillsides oriented towards preferential wind directions (as CR or IN sites, Table 1). The thicker snow covers are registered in plains (as some locations of CL or LL sites, Table 1) but also at protected hillsides (MO and NI sites, Table 1). We observed an increase in the snow cover duration until the year 2016 (de Pablo, 2016b), but the last few years do not strongly support that early observation. Snow was scarce during the year 2016-2019. The lack of data for some sites does not allow to assess this indubitably, but this behavior is especially evident in the CL, where snow cover is not only shallower but starts later in the year. Usually, the snow accumulates gradually, but melts much faster.

The new snow poles installed will allow to improve these results and our knowledge about the snow cover evolution. However, the most important contribution to the knowledge about the snow thickness evolution and properties comes from the new SPA station installed in Crater Lake CALM site in early 2016 (Fig. 2). The first improvement is the resolution on the snow cover depth measured by an USH-9 ultrasonic sensor (by Sommer Messtechnik), which provide one millimeter in accuracy hourly data. It also provides temperature data at different elevations measured by pt100 thermistors of the SCA instrument by Sommer Messtechnik, useful for refine the approaching of snow depth methods. We have been using classical methods based on mini temperature logger iButtons devices (Danby and Hik, 2007; Lewkowicz, 2008), but now we will be able to evaluate net differences between methods and devices with different accuracy. We will be able to correct then the results obtained from all our snow poles, or even propose another method that show less divergences.

Snow depth and snow weight measured by the cited ultrasound sensor and snow scale SSG-2 (by Sommer Messtechnik) integrated in the SPA station, respectively, will be used to derive snow water equivalent (SWE). Those parameters (depth and weight of the entire 


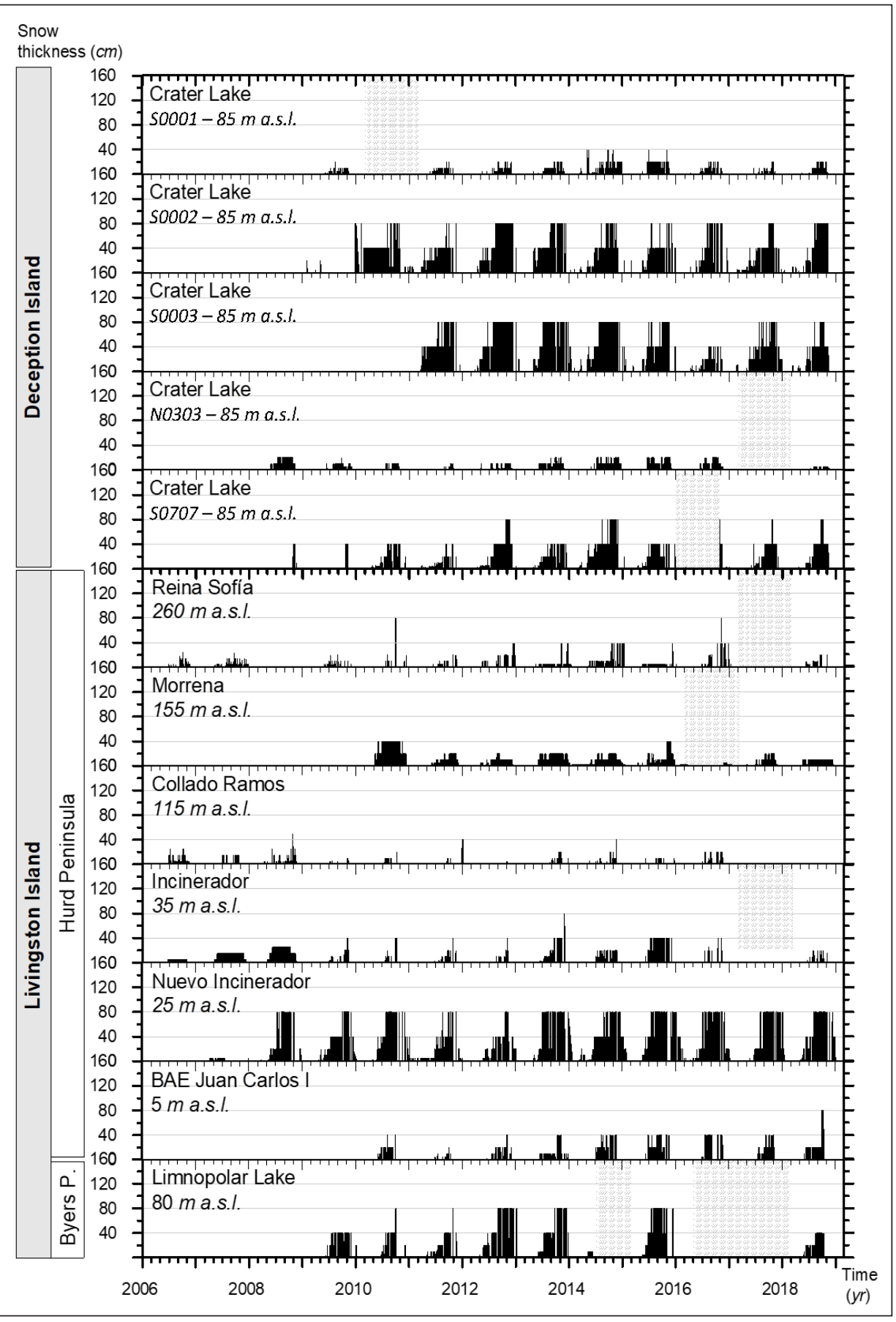

Figure 6. Snow cover evolution in our monitoring sites in Deception and Livingston Island, Antarctica, for 2006-2018 period. 
snow pack) could be compared with ice and water content, density and SWE measured at different elevations above the ground $(10,30$, and $50 \mathrm{~cm})$ to analyze el movement of the water inside the snow pack. This is important at the beginning of the melting season, when the water reaching the ground surface contribute both to snow thawing and to the formation of an ice layer between the snowpack and the ground surface. This ice layer isolates the soil from the increasing temperatures of spring and early summer (Marsh and Woo, 1984 as seen in Woo, 2012) and favors the existence of zero-curtain effect periods in the ground thermal evolution. This happens mainly in early thaw period (e.g., Cook, 1955; Kelley and Weaver, 1969; Outcalt et al., 1990), modifying the total balance of thaw, freeze, and isothermal days usually calculated to describe the thermal regime of the ground (e.g., Guglielmin et al., 2008; de Pablo et al., 2013; Hrbáček et al., 2016b; Oliva et al., 2017a).

The comparison of multiple SPA parameters (Fig. 7) allows a better understanding of the ground thermal behavior. The snow onset (blue line), offset (red line), and snow precipitation events (light green lines) during the summer are related to the decrease of the temperatures $\left(<0^{\circ} \mathrm{C}\right)$ and thermal amplitude. The increase on the snow cover because of the spring precipitations (dark green line) marks the beginning of the increase of the ground temperatures (although remaining below $0^{\circ} \mathrm{C}$ ), although the zero-curtain period starts at the beginning of the snow cover melting (black line), forming an ice layer at the base and remaining independently of the existence of latter snow cover variations in late spring or early summer (pink line). Ground surface remains under the zero-curtain effect also during the beginning of the runoff because the snow pack pores are completely saturated by the melting water (orange line). The changes in the evolution of the snow pack and its characteristics along the years (Fig. 7) explain together with the Ta (de Pablo et al., 2017) the differences on the ground thermal behavior. A detailed analysis of these data will help us to define in detail the processes that occurs in the snow pack and to quantify their effect on the ground temperatures. Later, we will be able to understand the evolution observed in the thermograms of the close boreholes (see next section).

Finally, the integrated pyranometers and pyrgeometers will allow to calculate the energy balance on site and to evaluate its effect on the snow cover melting and ground heating. These analyses are supported with the use of the daily weather observed with the time-lapse cameras (see previous section). The analysis of the radiation energy balance is not only a new input for snow cover and active layer and permafrost thermal regime investigation, but it will be also useful to derive albedo and to test the presence of snow on site (validated by all the other data from the SPA) correlated with satellite-derived albedo products, as we will see later in this work (Section 7.2).

\section{Snow cover influence on ground surface temperatures}

\subsection{Ground temperatures evolution}

The first step on understanding the thermal effect of the snow cover on the ground surface temperatures is to characterize the ground temperatures (de Pablo et al., 2010, 2013, 2014; Jiménez et al., 2103, 2016). To reach this objective, we used temperature data from different types of sensors installed inside boreholes drilled in Deception and 


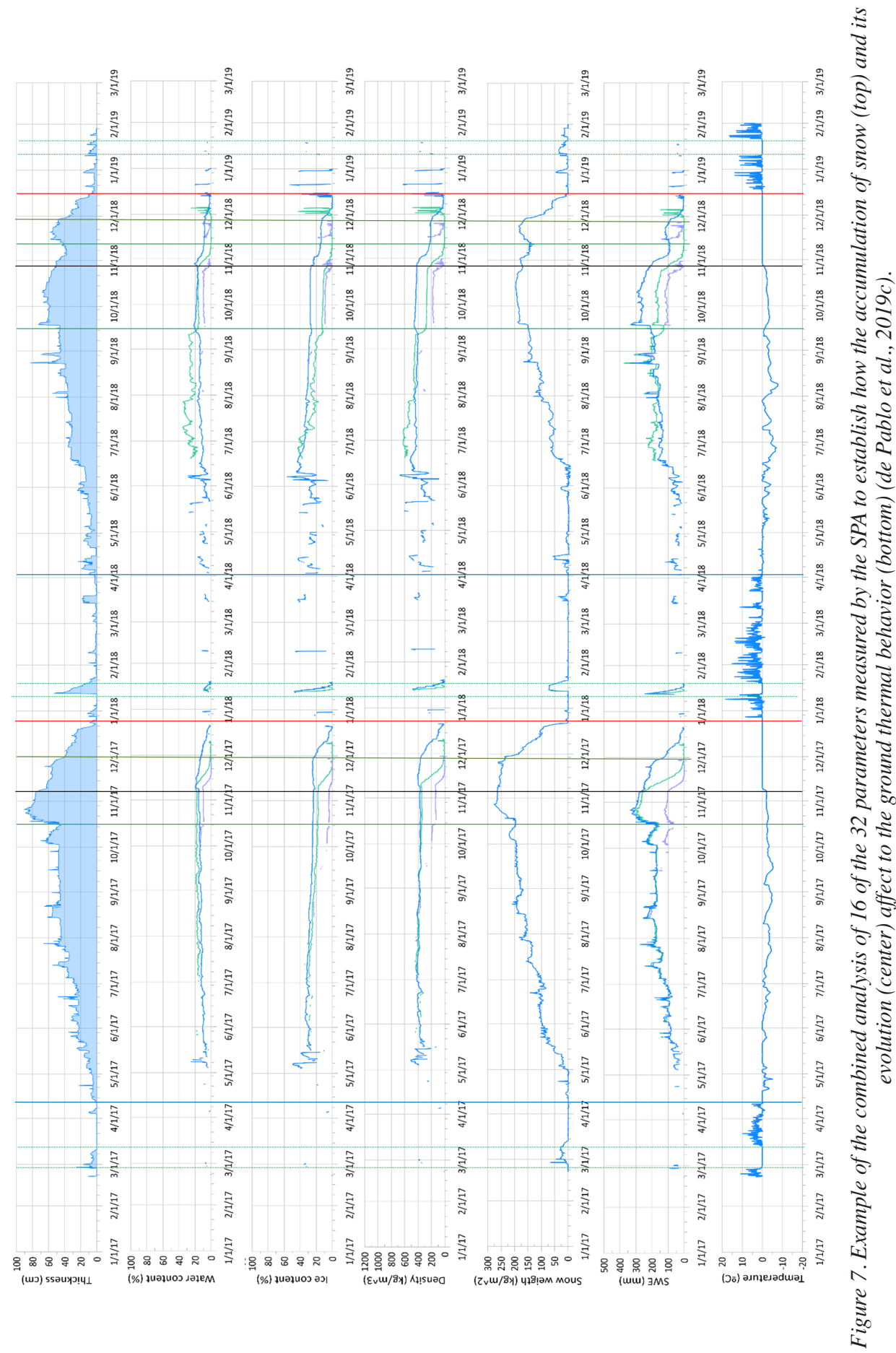


Livingston Islands with variable depths, from 1 to 25 meters. We cleaned the data and obtained the yearly maximum, mean, and minimum temperatures at each depth in the borehole to produce temperature profiles. There, the active layer thickness and the permafrost base depth could be observed, as well as, the annual zero thermal oscillation depth in some cases. Moreover, we calculated different parameters to quantify the freezing and heating of the ground at each depth in each borehole, including the Freezing Index, the Thawing Index (summatory of negative and negative temperatures, respectively; e.g., Houghton, 1985), and the n-factor (ration of Freezeing index of surface and air; e.g. Lunardini, 1978). Finally, we plotted thermograms to visualize the detailed evolution of the ground temperature along the 2006-2018 study period (Fig. 8).
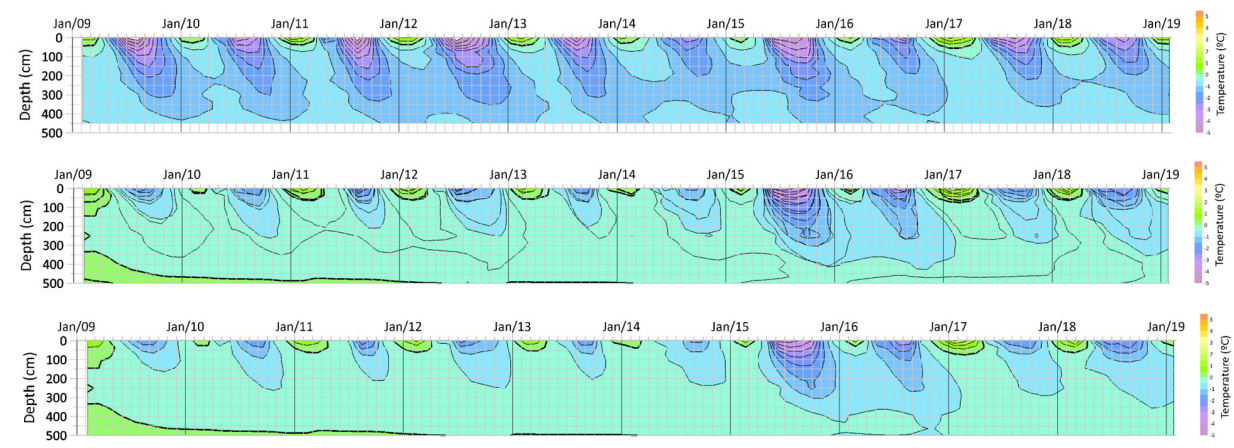

Figure 8. Example of the thermograms plotted from the ground temperatures registered in each one of our GTN-P boreholes in Deception Island, for the 2006-2018 period, showing the evolution of the permafrost temperatures, and active layer thickness, for each site.

Although we are still working on analyzing all these data (Fig. 8), a preliminary analysis shows that when the borehole reaches the base of the permafrost the temperature remains constant in depth during the complete study period, while the active layer thickness changes some centimeters each year depending on external environmental influences (as weather and snow cover). This variability changes from one site to another, depending on the site properties (elevation, relief, precipitation, wind, insolation). But in general, a reduction on the annual thermal variability has been reported (Morales, 2017; Morales and de Pablo, 2017), as well as an increase on the average temperatures (Ramos et al., 2016; Maior, 2018; Maior et al., 2019). These variations had been related to changes in snow cover duration and thickness (Ramos et al., 2016; de Pablo et al., 2016, 2018).

The analysis of the measured thawing depth during the Antarctic campaigns in both CALM sites (Table 1) revealed a complex behavior in which the active layer thickness was decreasing during the 2006-2016 period (Morales, 2017; Morales and de Pablo, 2017; de Pablo et al., 2018). The complementary analyses of TTOP and GT in the Crater Lake CALM site revealed that the ground temperatures were also increasing in the same period, even when the active layer was decreasing meanwhile the permafrost table increased (Ramos et al., 2016; Morales, 2017; Morales and de Pablo, 2017). These results agree 
with previous analyses of surface and air temperatures and the data from the snow poles from Limnopolar Lake CALM site that revealed a negligible increase on air temperatures and snow thickness. The surface isolation established by the calculated n-factor point to an increase on the isolation effect meanwhile the snow thickness calculated from snow poles reveals an elongation of the snow cover season (de Pablo et al., 2016). These results also agree with the analysis of GST measured in the Limnopolar Lake CALM site during the 2017-2018 period, also as part of the PERMASNOW project. There, the change on the snow cover offset (reaching more than 60 days, from one node to other in the grid) results in a very different active layer thickness and mean GST (de Pablo et al., 2019d). Therefore, we could confirm using different sources of data, from different sites and study periods, that the snow cover is affecting the ground thermal behavior, producing an increase on the temperatures of the ground due to isolation (by delaying the snow offset and reducing the thawing season), contributing to the increase of the permafrost instability.

\subsection{Ground temperatures modeling}

To quantify the observed effect of the snow cover on the GST, we started by modeling the GST from the Ta. The ground surface should have the same temperatures than the air in ideal conditions, but the surface materials' thermal conductivity result in a delay on the Ta (e.g., Zhang et al., 2005). Other parameters like moisture or lithology, also affect to the transmission of the temperatures to the ground. Vegetation, anthropic constructions, or snow also increase this delay (see Zhang et al., 2005 for a review). We assume that the effect of moisture and lithology is constant in our monitoring sites, and there is no vegetation. For that reason, any change on the transmission of the temperatures from the air to the ground should be related to snow cover presence and thickness, although solar radiation plays an important role too.

We started testing a simple multilinear regression analysis (MLRA) for the air (Ta in ${ }^{\circ} \mathrm{C}$ ) and ground surface (Ts in ${ }^{\circ} \mathrm{C}$ ) temperatures measured in the GTN-P station of the Limnopolar Lake site in Livingston Island between 2009 and 2014. We considered a third parameter in the egression, together with mean daily air (Ta) and surface temperatures (Ts) the (Model A) consider absence/presence of snow ( $\mathrm{Sn}$, taking values 0 or 1 , respectively), and (Model B) snow thickness ( $\mathrm{Sn}$ in $\mathrm{cm})$. Since the approach to the snow thickness using the snow poles and the thermal behavior of the data registered in its array of temperature sensors is not accurate, we used the daily variability of the GST to derive the presence/absence of snow (Mackiewicz, 2012) for the model A, and the snow thickness, approach following the Lewkowicz (2008) method for the model B. MRLA were calculated, in each scenario, for yearly data, and the complete dataset. To distinguish the effect of the snow, we also considered, in each scenario, the calculation of multilinear regression for the data when there is snow cover, the surface is snow-free, and for all the data (yearly or the entire dataset). In this way, 48 MLRA tests were applied.

The results of these analyses are statistically consistent with medium to high correlation coefficients returning different linear equation that explain more than the $60 \%$ of the ground surface variability. On the contrary to the expected, the use of snow thickness discrete values (in $\mathrm{cm}$ ) does not improve the results, obtaining similar 
correlation coefficients. We foresee that the use of continuous values of snow thickness could improve these equations, though, but further research is required. Both scenarios could be applied then with statistically similar results, depending on the available data.

The analysis of the results for the Limnopolar Lake site reveals that the snow cover has a relevant effect on the GST, reducing it in a $0.01-0.04{ }^{\circ} \mathrm{C} / \mathrm{cm}$ ratio, anon negligible value. The seasonal (thaw and snow) analysis of the MLRA results revealed a reduction in the Ta effect on the GST during the last years of the study, while the effect of the snow cover remains about constant. These effects agree with the previously reported reduction of the $n$-factor (i.e. reduction of the ground surface isolation) in this monitoring site, the similar annual snow thickness, and the elongation of the snow cover duration (de Pablo et al., 2016, 2017, 2018; Ramos et al., 2016).

We also modelled GST in order 1) to complete the time series of data,2) to characterize the thermal properties of the ground, and 3) quantify the effect of the snow cover on the ground temperatures. To reach this objective, we started to use the GIPL2 mechanistic numerical model (Jafarov et al., 2012) to the data of our GTN-P stations, developing the first tests with the data acquired in 2009-2016 at the Limnopolar Lake station (e.g., de Pablo et al., 2013, 2014, 2017a, 2017b). This model was initially developed by Tipenko et al. on 2004 and later modified and used by Marchenko et al., 2008, Jafarov et al., 2012,2014; Nickolsky 2007, 2009, 2017 and many others. GIPL2 model is a mechanistic numerical model coded on Fortran. It uses phase changes formulation and the effect of unfrozen volumetric water in the multi-layered soil texture. The input data required to run the model are: daily snow depth and thermal conductivity and mean daily temperatures at different elevations (Ta) and depths (ground temperature), at the user-defined depths array. Initial temperature data at the depth arrays on the first timestep is also required. Different thermo-physical parameters for the different ground horizons are required, including volumetric water content, coefficients of the unfrozen water curve, thawed and frozen volumetric heat capacities and conductivities and layer thickness, that could be obtained from bibliography, or in situ or in laboratory measurements when samples are available. The output of the model includes mean daily temperatures at the selected depths for the complete running period of the model, and yearly averaged data such as annual temperatures, active layer thickness, freeze up day and so on.

Due to the relative complexity of the model, we are still working on the adjustment of the ground properties since the thermo-physical parameters are still not well adjusted, and the results are not accurate enough (Fig. 9). These ground parameters have been initially obtained from the literature considering the geological properties of the monitoring site. However, for the next iterations, real data will be used thanks to those acquired during the 2018-19 Antarctic campaign in the monitoring sites, as well as the future analysis that will be done to the sediment's samples. We expect, to be able, not only to model the already acquired data, but to deduce the real effect of the snow cover on the ground temperatures, under different conditions, including the Snow Water Equivalent. Finally, the adjustment of the model will allow the prediction of the ground thermal evolution under different Ta increasing ratios due to climate warming scenarios, as well as under different snow thickness conditions. Application to all our GTN-P monitoring sites is also a future task. 


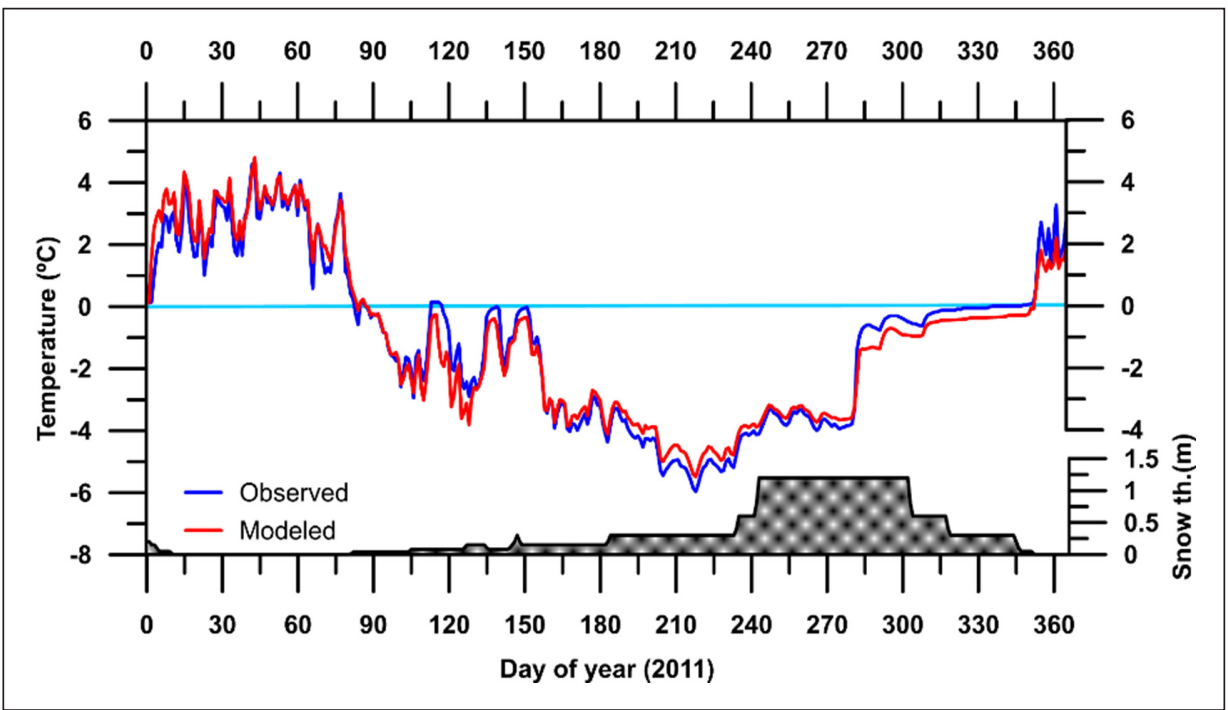

Figure 9. Example of the present results of the GIPL2 modeling of ground temperatures in Limnopolar Lake borehole, Livingston Island. Although error is lower than $0.2^{\circ} \mathrm{C}$, further improvements are required.

\section{Remote sensing}

\subsection{Air temperature}

The objective with the thermal MODIS data was to obtain empirical models for estimating daily mean Ta using Land Surface Temperature (LST) MODIS data (and other variables), in order to obtain Ta maps from LST data in, at least, the whole of the Hurd Peninsula, where the study was done. Ta is widely used to estimate the possible existence of permafrost (Westermann et al., 2011; 2012), and, therefore, we will be able to estimate the possible existence of permafrost in the South Shetland Islands based on this parameter and tested with the ground-true data provided by our GTN-P stations. Differences with measured data could be caused by relief, lithology, or snow cover properties in each site.

For this research, the comparison between in situ Ta and LST data used daily mean Ta from three Spanish meteorological stations (AEMET stations): Juan Carlos I (JCI), Johnson Glacier (JG) and Hurd Glacier (HG), and 3 of our GTN-P stations, because each of them corresponds to a different MODIS pixel and different LST value: INC, SO and CR (Table 1); and daytime and nighttime, Terra and Aqua, MODIS LST (MOD11/ MYD11 product; $1 \mathrm{~km}$ of spatial resolution) between 2000 and 2016. Both types of data were studied in detail previously to the comparison to ensure its reliability and quality.

The analysis of the Ta time series revealed that the stations nearest to the coast (JCI) showed a clear cooling trend (between -2.3 and $-3.0^{\circ} \mathrm{C} /$ decade) whereas the other higher 
altitude stations showed warming trends (between +0.2 and $+0.8^{\circ} \mathrm{C} /$ decade), indicating a complex climatic variability in the Hurd Peninsula. The Ta linear trend was obtained by the Locally Weighted Regression (LOESS) method (Cleveland, 1979; Cleveland and Davlin, 1988) in each station, except for HG, due to the lack of data (Fig. 10). The study also showed that the Ta data are very reliable and that they are highly correlated between stations. The three AEMET stations are correlated with $\mathrm{R}^{2}$ values as from 0.89. In addition, we compared the Ta of the highest stations, Reina Sofía and Collado Ramos, with the Ta of the lowest stations, JCI (in its two locations, JCI1 and JCI2) and Incinerador, and we obtained $\mathrm{R}^{2}$ values higher or close to 0.90 in most cases (JCI2-Reina Sofia, Incinerador-Collado Ramos, JCI2-Collado Ramos, JCI1-Collado Ramos), except Incinerador-Reina Sofia and JCI1-Reina Sofia, $\mathrm{R}^{2}=0.79$.

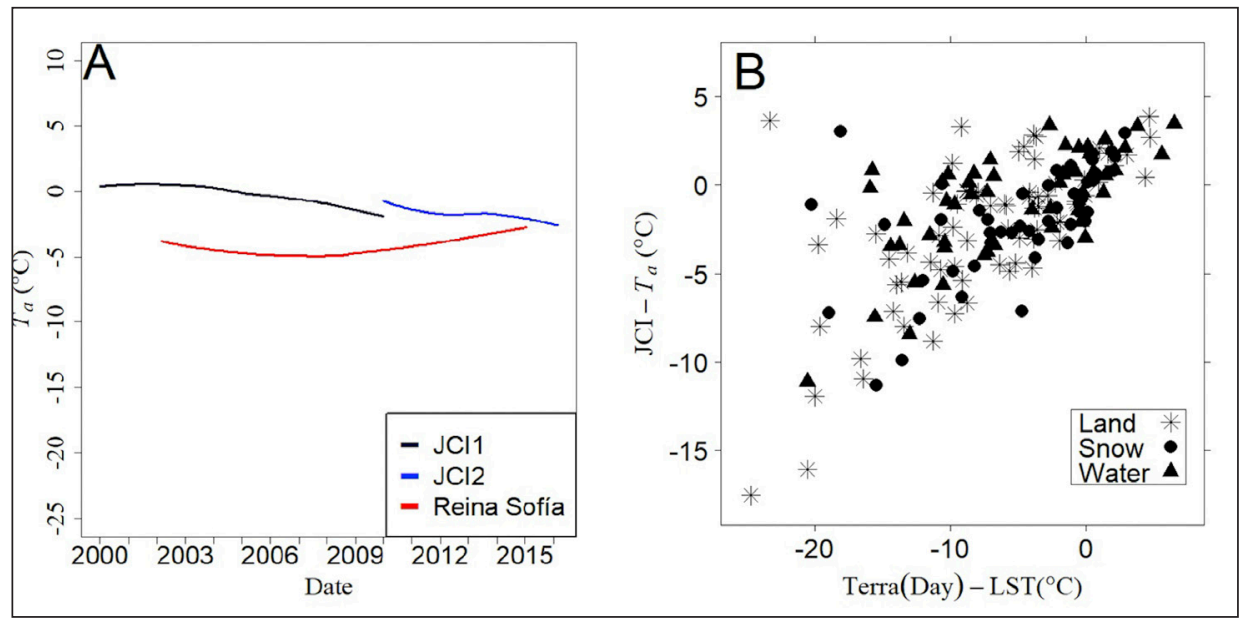

Figure 10. A) Example of Ta linear trend obtained with the LOESS method for JCI1 (black line), JCI2 (blue line) and RS station (red line). (B) Relationship between the daily mean Ta and the diurnal LST from Terra-MODIS in JCI (station shown as an example) with "good" data after applying all the quality filters.

The MODIS LST data needed to be filtered not only of cloudiness (mask already included in these data), but also according to its quality, and only the "good quality" were considered suitable. The quality filters of the MODIS albedo product (MOD10/ MYD10; $500 \mathrm{~m}$ of spatial resolution) were also used to improve the filtering of the LST data. Because of the filtering, the LST data were drastically reduced $(<5 \%$ of the studied days) and eliminated all in HG. So, only models for the five remaining stations were obtained. The most representative stations were selected as examples (Fig. 10): JCI (in its two locations), station with the highest cooling trend and Reina Sofía, which has the highest warming trend.

In summary, although the "good" MODIS LST data in these cold environments are scarce, all the months were represented, concluding that the MODIS LST data are useful for estimating long-term trends in Ta at a global level ( $1 \mathrm{~km}^{2}$ of spatial resolution) 
in the Hurd Peninsula of the Livingston Island (Recondo et al., 2019). This study also contributes to the analysis of the permafrost distribution, because Ta is widely used to determine the possible presence of continuous, discontinuous and sporadic permafrost (Ives, 1974; Smith and Riseborough, 2002 and references therein), such as others already did in the past in artic or mountain permafrost areas (e.g., Keller, 1992; Hoelzle et al., 1993; Westermann et al., 2011; 2012; Azocar et al., 2017). Based on this idea, our study will open the path to model permafrost distribution in South Shetland Islands.

\subsection{Albedo}

The albedo is a fundamental parameter in climatic and meteorological models since it determines the energy exchange between the atmosphere and the Earth's surface. The main objective in the framework of the PERMASNOW project is to describe the albedo distribution using remote sensing data, because it could be an important source of distributed information of the snow cover presence and its properties. In this way, we attend to establish the procedure to develop snow cover maps of the South Shetland Islands by remote sensing. Two lines of action have been carried out: 1) performance of in-situ distributed albedo measurements, and 2) relating the albedo trend and seasonality from satellite data and in-situ data.

During the 2017-18 and 2018-19 campaigns, we have carried out distributed albedo measurements over Deception and Livingston Islands using the instruments described in Section 2.4. Different surface types were sampled to obtain some properties of the superficial snow at the same time: snow density, hardness, water content, temperature by snow pits. Taking into account that albedo measurement is recorded every five seconds, the number of acquisitions depended on the size of the surface patch being sampled, the accessibility of the patch, the homogeneity of the surface and the stability of the weather conditions during the acquisition. The number of acquisitions for each type of surface was: mixed-surface snow-small spots of bare soil: 70; bare soil: 45; dirty snow: snow with lapilli: 39; mixed surface: snow (80\%), bare soil (20\%): 202; clean snow on slope facing south: 124; clean snow mixed with patches of dirty snow: 91 ; clean snow (advanced metamorphism): 153; mixed surface: now (70\%), bare soil (30\%): 149; mixed surface: snow (30\%), bare soil (70\%) 118; beach 1: 566; beach 2: 117; seashore: 407; fresh, clean snow (low metamorphism): 311 . For each sampled surface, the histograms of albedo were fitted to a normal distribution (Fig. 11).

Next step is to use this data to classify the albedo maps based on these characterized surfaces (Fig. 12). However, albedo maps of Antarctica have been obtained up to date with a spatial resolution of $5 \mathrm{~km}$ (Laine, 2008), too low to describe the influence of the snow cover on the permafrost active layer. Then, we tested the capability of midresolution satellite data to track the albedo trend and seasonality over Livingston Island. We have compared the albedo trend and seasonality from in-situ data and from MODIS at Johnsons Glacier AEMET station. We have used the MODIS daily snow albedo product MOD10A1 (v5) with a spatial resolution of $500 \mathrm{~m}$. In order to minimize the noise, insitu data have been filtered with a 5-day window moving average, whereas a maximum filter has been applied onto MOD10A1 data using images from three consecutive dates 


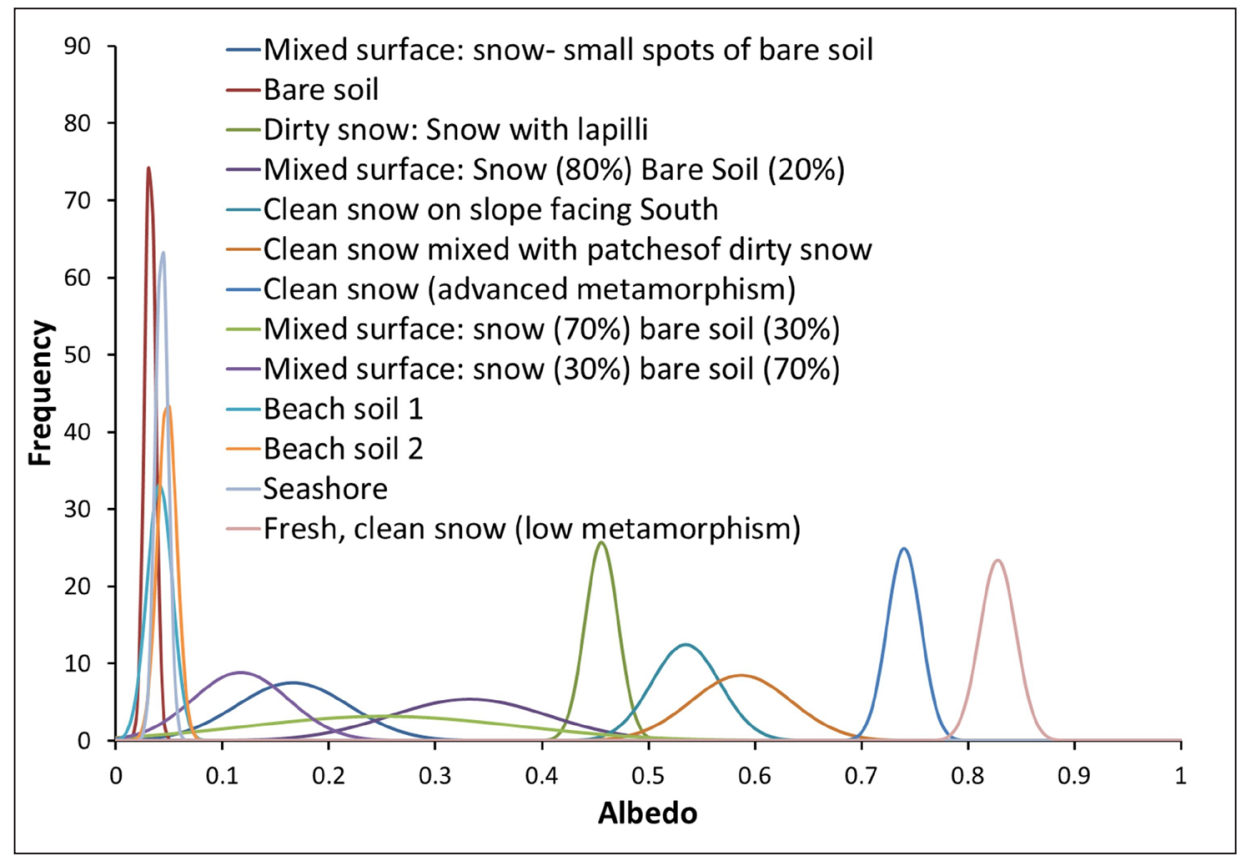

Figure 11. Albedo distribution of the surface types representative of the landscapes of Deception Island.

of MODIS data (not necessarily three consecutive calendar dates). In this way we ensure that the influence of extremely low values is minimized while the seasonal variations of in-situ albedo are reproduced (Calleja et al., 2019).

Regarding the albedo decay, we observed an early onset of the decay (early September) and duration between 85 days for the 2007-2008 season and 167 for the 2013-2014 season (Calleja et al., 2019). The values and duration of the albedo decay agree with results obtained in the Antarctic Peninsula (Malik et al., 2012; Barrand et al., 2013). In-situ data exhibit an increase of $0.02(2 \%)$ in in-situ albedo and $0.06(6 \%)$ in MOD10A1 albedo from December 2006 to February 2015, probably due to a reduction of summer melting. It is well known that snow melting decreases the albedo (Warren, 1982) due to the snow grains evolution and the lower reflectance of liquid water, in agreement with recent investigations showing a decrease of summer melting in the Livingston Islands (Navarro et al., 2013; Sancho et al., 2017; de Pablo et al., 2017a), more accurate in the last decade, as a result of the widespread cooling over most of the Antarctic Peninsula (van Wessem et al., 2016). This will be studied in the future in situ thanks to the SPA installed in Deception island in 2016 (de Pablo et al., 2019c). Then, due to the relatively low resolution of these MODIS-derived albedo products $(500 \mathrm{~m} /$ pixel) could be used to study regional albedo distribution in the South Shetland Islands and, therefore, the snow cover distribution and properties using the already described in situ albedo characterization of different surfaces. 


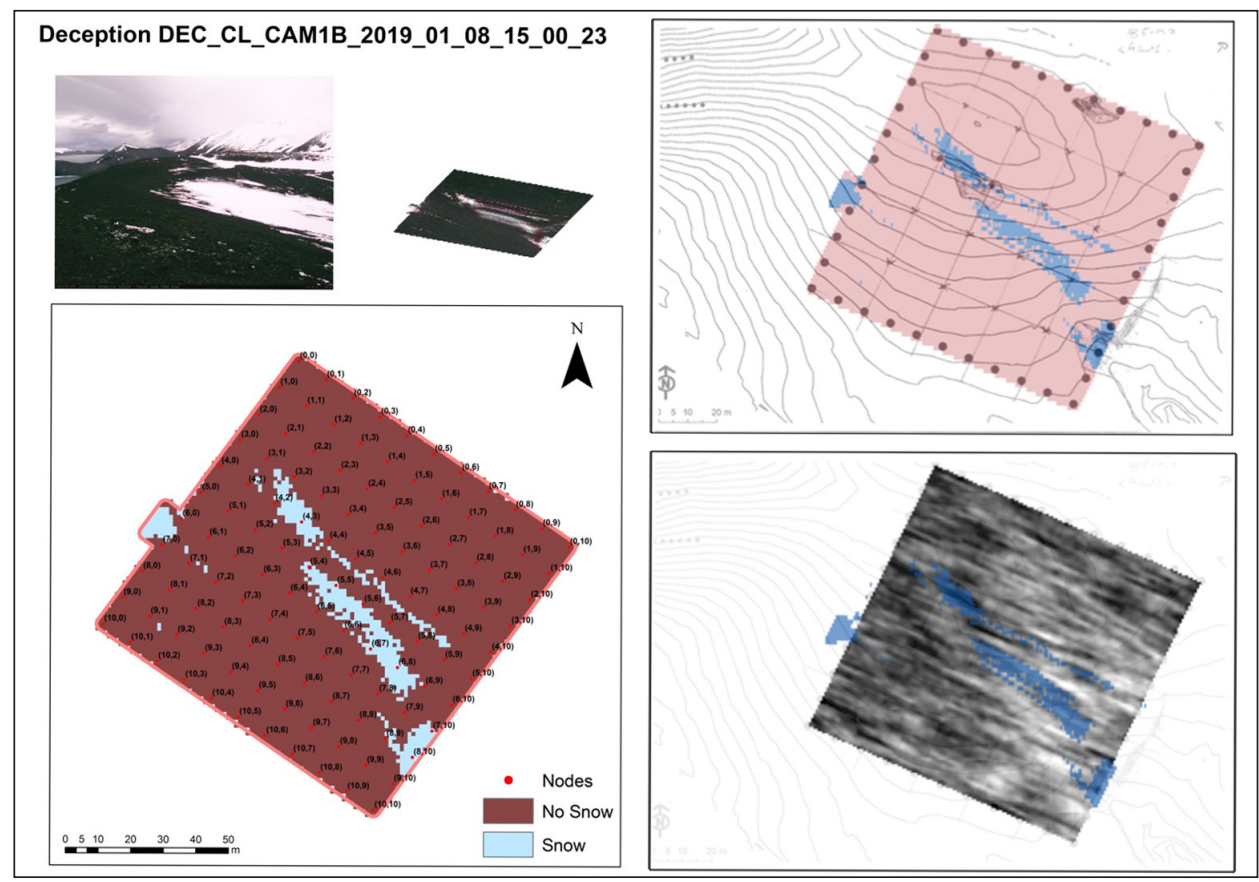

Figure 12. Left: Snow cover map of Crater Lake CALM site in Deception Island obtained by means of photographic time-lapse camera, 8th January 2019. Right upper: Snow cover map (deep black) on trial drawn with superimposed classification map. Right down: backscattering response over tested surfaces 8th January 2019, Radar X band, HH polarization, 21'4 ${ }^{\circ}$ incidence angle, descending orbit, 08:49 UTC.

\subsection{Snow cover detection by RADAR}

Despite the good results we obtained by the use of optical satellite images (MODIS), the optical sensors have many inconveniences in cloudy areas, and the data are too coarse to conduct high spatial resolution studies of permafrost. To avoid it, we started to applicate Radar techniques (Venkataraman et al., 2013; Mora et al., 2013, 2017) to evaluate the presence of snow coverage throughout the year. We started working with 46 images acquired between 2016 and 2019 by the TerraSAR X sensors of the DLR space platforms (Deutsches Zentrum für Luft- und Raumfahrt, German Government) in Staring SpotLight mode thanks a research project approved by DLR, covering the Crater Lake CALM site study area on Deception Island (Jiménez et al., 2018). Some of the images were coincident with the dates of the Antarctic fieldtrips carried out to take ground-true data (snow cover maps and snow pits). The acquisition plan, images characteristics and processing tasks were explained in Jiménez et al. (2019b).

During the Antarctic Campaigns developed in Deception island in early 2017, 2018 and 2019, snow cover was mapped on-site and snow pits were carried out in the vicinity of the CALM site in order to qualify the snow condition (degree of humidity, 
presence of snow ice, snow water equivalent, layer thickness and other physical parameters) and its correspondence with the backscattering detected by the TerraSAR $X$ sensors. These measurements, together with the time-lapse images, have been established as a ground-truthing reference for the subsequent surface classification phase (snow/no snow) (Fig. 12). Additionally, distributed GST data, as well as snow thickness derived from the snow poles, and the data from the SPA station were also used for the confirmation of snow/non-snow classifications.

After the processing and analysis of the images and data, we were able to establish recurrent snowing patterns (within the wide variability of meteorological conditions present in the area) that shows a tendency to increase days of snowing and, what is more relevant, a temporary shift towards later snowfalls, so that snow cover with its large thermal insulation capacity is generating favorable conditions for the accretion of the active layer and the underlying permafrost, such as it was already reported for the Crater Lake CALM site (Ramos et al., 2016). The first results we have been obtaining allow the production of snow cover maps for the monitoring site, and points toward a close future in which we will be able to map the snow cover of the entire island for different dates, that is the first step to know the permafrost distribution in the island. However, this topic is still under evaluation, given that the soil and air energy interchange is blocked at times when the atmospheric temperatures would force defrost cycles, which are delayed in this way by the previous isolation effect. This effect could be concurrent with the global absence of warming in the Antarctic Peninsula (Turner et al., 2016) in opposite response to global warming observed in other areas of Antarctica.

\section{Instrumentation improvement and innovation}

\subsection{Permarduino and Snow Pack Portable Sounder}

Simultaneously to the purely scientific research, we carried out different technical innovations along the PERMASNOW project, including the development of our own datalogger (Permarduino) for register the air, snow, surface and ground temperatures (de Pablo et al., 2014, 2015, 2017, 2019b), and a portable device to measure and store snow thickness and bottom and surface snow cover temperatures (Snow Pack Portable Sounder) on each position registered by the integrated GPS unit (de Pablo et al., 2019e). Both devices (Fig. 13) are based on open-hardware Arduino board (e.g., Arduino, 2014; Louis, 2016), trying to reduce the costs of this kind of commercial scientific instruments, and adjusting them to our own requirements.

Permarduino, powered by a $6 / 12 \mathrm{~V}$ battery charger with a $20 \mathrm{~W}$ solar panel, have 5 monitoring channels which could support up to 50 1-wire DS18B20 digital temperature sensors (By Maxim Co.) in each channel with a maximum distance of $200 \mathrm{~m}$ from the device. In our testing station installed in Livingston island, we used these channels to hourly monitor air (1 sensor), snow (15 sensors), bottom snow (1 sensor), surface (1 sensor), and ground temperature (10 sensors), stored as an ASCII file in the integrated SD card. The firmware tries to keep the use as simple as possible and plug-and-play philosophy was assumed to the maintenance and replacement of 


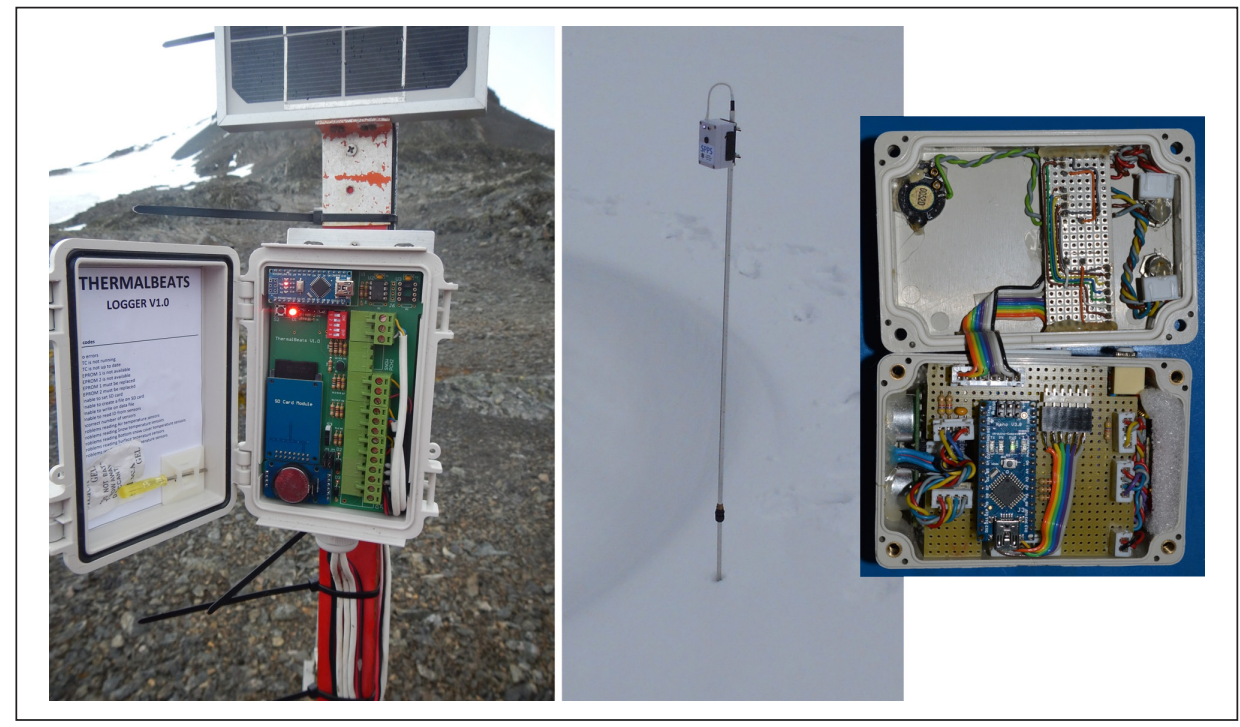

Figure 13: Pictures of our Arduino-based (left) Permarduino datalogger installed in Antarctica, and the Snow Pack Portable Sounders (center and right) we developed to help in our research of the snow pack along the PERMASNOW project.

the sensors, requiring the use of a unique button to start/test/configure the device, and a microswitch to configure the operative channels (de Pablo et al., 2014, 2015, 2017, 2019b).

Snow Pack Portable Sounder (de Pablo et al., 2019d) consists on an expandable (not extensible) aluminum mast with a waterproof temperature probe (DS18B20 digital sensor) on an extreme to measure the basal temperature of the snow cover. On the other extreme, the main electronic box (sensors unit) is installed containing an IR temperature sensor (MLX90614) to measure the snow cover surface temperature, and an ultrasonic distance sensor (HC-SR04) to derive snow depth. A miniature GPS antenna (GPS-NEO-6M-001) provides location of each measurement. The device is powered by four $1.5 \mathrm{~V}$ AA batteries. Human interface consists on a push button to take the measurements of all the sensors, and a buzzer and a RGB led inform about the state of the measurement as well as possible errors. The data are stored as an ASCII file into a microSD card thanks to a miniature SD module. The core of this device is an Arduino board as well. We used this device in the last Antarctic campaigns to test it meanwhile we mapped the snow cover distribution for the ground-truing required for the remote sensing research.

\subsection{Communications}

Another important technical improvement done along the PERMASNOW project was try to establish a link between our Antarctic monitoring stations and our offices in Spain to check the data and the proper working of the stations in order to plan and organize 
properly the Antarctic campaigns without the use of costly satellite communication systems, and considering the harsh Antarctic environmental conditions, which led to a low power and rugged wireless solution. The under-test solution consists on radio communications among one of the GTN-P station (Table 1) and the closest Antarctic Station (short range segment), where the data are emitted outside the Antarctica to be injected in internet (long range segment), where the data are available for the research team through a web site.

The testing station was CL-S3 GTN-P site (Table 1), located at about $1 \mathrm{~km}$, no line-of sight, from the Spanish Antarctic Station "Gabriel de Castilla" (GdC). In the CL-3 site, a prototype of VHF radio transmitter, named Permaradio, was installed in early 2016 (Fig. 14). After some improvements, it consists on a PCB board with a STM8 microcontroller to interface the CR1000 datalogger of the station and an AFSK modulator acting as a full APRS radiomodem. A Baofeng UV-3R handheld was used as radio transmitter (up to 2 watts). The details of the radiomodem and components and configuration were briefly described in (Prieto et al., 2017). As for the GdC end-point, a receiver module, named RIGA, was connected to the GdC infrastructure, obtaining the power from a wind turbine during winter. RIGA is composed of a Raspberry Pi computer module which controls a Software Defined Radio Receiver RTL-SDR. RIGA tunes the receiver at the desired frequency, decodes AFSK data frames and dialogues with the satellite link provided by the Antarctic Station. GdC uses Inmarsat platform as the satellite link service during winter season. Raspberry Pi is connected to the satellite datalogger via an Ethernet connection (Fig. 14).

The Permaradio prototype has survived 3 full Antarctic years with low maintenance. However, the main problem we found was in the satellite link because every year the Inmarsat satellite modem of the GdC stopped working around mid-June for different reasons. Despite that, we were able to receive in Spain, through a webpage, the data from

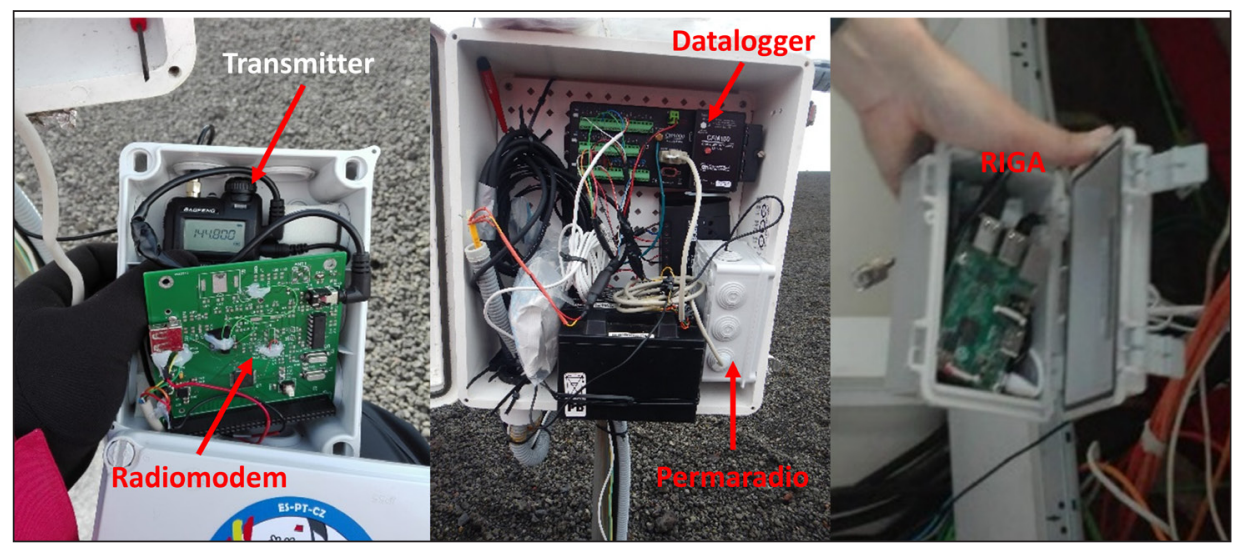

Figure 14: Permaradio radio modem (Left) installed to recover the temperature data from $C L$ $S 3$ borehole datalogger (Center) to send them to the GdC station where it is captured by the raspberrypi-based RIGA device (Right) and injected on the satellite link (not shown). 
CL-S3 site in Antarctica until the satellite link failed. It means that the tested solution is feasible considering the technical requirements and the harsh weather conditions.

After our successful experience with Permaradio and the HF data link, we plan to build an improved version of the prototypes considering all the lessons that we have learned in the last 3 years, that will open the path for the complete automatization of the GTN-P stations of our research group, allowing to be focused on the science and not also in technical maintenance operations during the Antarctic campaigns.

\section{Conclusions}

Along this work we presented the different new instruments installed in Deception and Livingston Islands, Antarctica, to study the snow cover and how it affects the ground thermal behavior, since we observed changes in the last years. Although we are still working on the data analyses, the first results of the time -lapse cameras images, TTOP, GST and snow poles data analysis are very revealing. The data show how snow cover is not increasing significantly in thickness but changing the offset dates, delaying the ground thawing. Consequently, the snow layer does not allow it's the ground freezing enough during the early winter, contributing to 1) the reduction of the active layer thickness, 2) the increase on the permafrost temperatures, and 3) the reduce of their annual thermal amplitude, in agreement with previous works.

Snow Pack Analyzer resulted to be a successful station providing a wide variety of data useful for the interpretation of the ground thermal behaviors observed on the data. Moreover, its data are been using for multiple purposes, such as the evaluation of the snow depth calculation methods from snow poles, the obtain an equation to correlate the Ta and GST considering the snow presence and snow depth, or even, the n-Factor when snow poles are not available.

The data from the SPA, analyzed together with all the other data from our extensive instruments network, will allow detailed correlations among Ta and GST and snow cover, as their modeling with help of in situ and laboratory thermophysical parameters measurements of local rocks and sediments. These models will allow prediction of permafrost behavior under different global warming scenarios.

On the other hand, the remote sensing tasks have been also successful and open the way to further research to develop permafrost maps of the entire islands. Satellitederived Ta data together with elevations model, radiation data, and other complimentary data will be key to produce snow cover maps based on the albedo data from satellite data. These products combined with the in-situ albedo characterization for the different type of surface coverages will allow develop regional snow cover maps as well. High resolution Radar-derived snow cover maps open the way for detailed analysis of permafrost and snow cover correlations.

Under the present global warming scenario, permafrost will be in danger, and the instruments, techniques and methodologies we briefly presented here will be fundamental to monitor, quantify and predict the thawing of the permafrost in the close future in the South Shetland islands, Antarctica. 


\section{Acknowledgements}

This work has been supported by funds from the Ministry of Economy of the Government of Spain by the Polar Research Program (PERMASNOW CTM201452021-R) and the PERMATHERMAL arrangement between the University of Alcalá, the Spanish Institute of Geology and Mining, and the Spanish Polar Committee for the maintenance of the monitoring stations in Deception and Livingston Islands. We thank to the 2016-2017, 2017-2018 and 2018-2019 crews of Gabriel de Castilla and Juan Carlos I Spanish Antarctic Stations in Deception and Livingston Islands respectively for their support on the development of the field tasks of the PERMASNOW project. Part of this research was possible thank to the Research Agreement with the Deutsches Zentrum für Luft-und Raumfahrt (German Government) for the acquisition of TerraSAR X images. Authors want to thank to the two anonymous referees for their useful comments that helped to improve the manuscript.

\section{References}

Abramov, A., Davydov, S., Ivashchenko, A., Karelin, D., Kholodov, A., Kraev, G., Lupachev, A., Maslakov, A., Ostroumov, V., Rivkina, E., Shmelev, D., Sorokovikov, V., Tregubov, O., Veremeeva, A., Zamolodchikov, D., Zimov, S. 2019. Two decades of active layer thickness monitoring in northeastern Asia. Polar Geography. https://doi. org/10.1080/1088937X.2019.1648581.

Arduino CC 2014. Arduino: Introduction. [Online] https://www.arduino.cc/en/Guide/Introduction. [Accessed: 23-December-2019]

Barrand, J.S., Vaughan, N.E., Steiner, D., Tedesco, N., Kuipers Munneke, M., van den Broeke, M., Hosking, M.R. 2013. Trends in Antarctic Peninsula surface melting conditions from observations and regional climate modeling. Journal of Geophysical Research Earth Surface 118, 315-330.

Bauer F.H., Taylor D., White R.A., Amend, O. 2019. Educational Outreach and International Collaboration Through ARISS: Amateur Radio on the International Space Station. In: H. Pasquier, C. Cruzen, M. Schmidhuber, Y. Lee (Eds), Space Operations: Inspiring Humankind's Future. Springer.

Ben-Dor, E., Chabrillat, S., Dematte, J.A.M., Taylor, G.R., Hill, J., Whiting, M.L., Sommer, S. 2009. Using imaging spectroscopy to study soil properties. Remote Sensing of Environment 113, S38-S55. https://doi.org/10.1016/j.rse.2008.09.019.

Biskaborn, B.K., Lanckman, J.P., Lantuit, H., Elger, K., Dmitry, S., William, C., Vladimir, R. 2015. The new database of the Global Terrestrial Network for Permafrost (GTN-P). Earth System Science Data 7, 245-259. https://doi.org/10.5194/essd-7-245-2015.

Biskaborn, B.K., Smith, S.L., Noetzli, J., Matthes, H., Vieira, G., Streletskiy, D.A., Schoeneich, P., Romanovsky, V.E., Lewkowicz, A.G., Abramov, A., Allard, M., Boike, J., Cable, W.L., Christiansen, H.H., Delaloye, R., Diekmann, B., Drozdov, D., Etzelmüller, B., Grosse, G., Guglielmin, M., Ingeman-Nielsen, T., Isaksen, K., Ishikawa, M., Johansson, M., Johannsson, H., Joo, A., Kaverin, D., Kholodov, A., Konstantinov, P., Kröger, T., Lambiel, C., Lanckman, J.P., Luo, D., Malkova, G., Meiklejohn, I., Moskalenko, N., Oliva, M., Phillips, M., Ramos, M., Sannel, A.B.K., Sergeev, D., Seybold, C., Skryabin, P., Vasiliev, A., Wu, Q., Yoshikawa, K., Zheleznyak, M., Lantuit, H. 2019. Permafrost is warming at a global scale. Nature Communications 10, 1-11. https://doi.org/10.1038/s41467-01808240-4. 
Bockheim, J., Vieira, G., Ramos, M., López-Martínez, J., Serrano, E., Guglielmin, M., Wilhelm, K., Nieuwendam, A. 2013. Climate warming and permafrost dynamics in the Antarctic Peninsula region. Global and Planetary Change 100, 215-223. https://doi.org/10.1016/j. gloplacha.2012.10.018.

Brown, J., Nelson, F.E., Hinkel, K.M. 2000. The circumpolar active layer monitoring (CALM) program research designs and initial results. Polar Geography 3, 165-258.

Calleja, J.F., Corbea-Pérez, A., Fernández, S., Recondo, C., Peón, J., de Pablo, M.A. 2019. Snow albedo seasonality and trend from MODIS sensor and ground data at Johnsons Glacier, Livingston Island, Maritime Antarctica. Sensors 19, 3659. https://doi.org/10.3390/ s19163569.

Chang, C.W., Laird, D.A., Mausbach, M.J., Hurburgh, C.R. 2001. Near-infrared reflectance spectroscopy-principal components regression analyses of soil properties. Soil Science Society of America Journal 65, 480-490. https://doi.org/10.2136/sssaj2001.652480x.

Cook, F.A. 1955. Near surface soil temperature measurements at Resolute Bay, Northwest Territories. Arctic 8 (4), 237-249. https://doi.org/10.14430/arctic3822.

Corripio, J.G. 2004. Snow surface albedo estimation using terrestrial photography. International Journal of Remote Sensing 25, 5705-5729. https://doi.org/10.1080/01431160410001709002.

Croft, H., Kuhn, N.J., Anderson, K. 2012. On the use of remote sensing techniques for monitoring spatio-temporal soil organic carbon dynamics in agricultural systems. Catena 94, 64-74. https://doi.org/10.1016/j.catena.2012.01.001.

Danby, R.K., Hik, D.S. 2007. Responses of white spruce (Picea glauca) to experimental warming at a subarctic alpine treeline. Global Change Biology 13 (2), 437-451. https://doi.org/10.1111/ j.1365-2486-2006.01302.x.

de Pablo, M.A., Blanco, J.J., Molina, A., Ramos, M., Quesada, A., Vieira, G. 2013. Interannual active layer variability at the Limnopolar Lake CALM site on Byers Peninsula, Livingston Island, Antarctica. Antarctic Science 25 (2), 167-180.

de Pablo, M.A., Ramos, M., Molina, A. 2014. Thermal characterization of the active layer at the Limnopolar lake CALM site on Byers Peninsula (Livingston Island), Antarctica. Solid Earth 5, 721-739. https://doi.org/10.1017/S0954102012000818.

de Pablo, M.A., de Pablo, C., Ramos, M. 2015. Improvements on Permarduino prototype device for active layer and permafrost thermal monitoring, and automatic digital camera development. V Conferencia Ibérica de la International Permafrost Association, Valladolid, Spain. Abstract, 23.

de Pablo, M.A., Ramos, M., Molina, A., Vieira, G., Hidalgo M.A., Prieto, M., Jiménez, J.J., Fernández, S., Recondo, C., Calleja J.F., Peón J.J., Mora, C. 2016. Frozen ground and snow cover monitoring in the South Shetland Islands, Antarctica: Instrumentation, effects on ground thermal behaviour and future research. Cuadernos de Investigación Geográfica 42 (2), 475-495. https://doi.org/10.18172/cig.2917.

de Pablo, M.A., Ramos, M., Molina, A. 2017a. Snow cover evolution, on 2009-2014, at the Limnopolar Lake CALM-S site on Byers Peninsula, Livingston Island, Antarctica. Catena 149 (2), 538-547. https://doi.org/10.1016/j.catena.2016.06.002.

de Pablo, M.A., de Pablo, C., Prieto, M. 2017. Permarduino datalogger for thermal monitoring of permafrost and active layer. In: J. Ruiz-Fernández, C. García-Hernández, M. Oliva, C. Rodríguez-Pérez, D. Gallinar (Eds.), Ambientes periglaciares: avances en su estudio, valoración patrimonial y riesgos asociados, Universidad de Oviedo, 181.

Fernández, S., Gallego, M.J., de Pablo, M.A., Ramos, M., Vieira, G. 2017. Análisis de patrones de nieve y sus relaciones con la temperatura del aire y del suelo en series temporales de fotografía digital RGB, CALM-S Crater Lake, isla Decepción, Antártida. In: J. RuizFernández, C. García-Hernández, M. Oliva, C. Rodriguez-Pérez, D. Gallinar (Eds.), 
Ambientes periglaciares: avances en su estudio, valoración patrimonial y riesgos asociados, Universidad de Oviedo, pp. 207-215.

de Pablo, M.A., Ramos, M., Molina, A. 2018. Thaw depth spatial and temporal variability at the Limnopolar Lake CALM-S site, Byers Peninsula, Livingston Island, Antarctica. Science of the Total Environment 615, 814-827. https://doi.org/10.1016/j.scitotenv.2017.09.284.

de Pablo, M.A., Molina, A., Ramos, M., Vieira, G., Prieto, M., Hidalgo, M.A., Jiménez, J.J. 2019a. Snow cover thickness evolution on 2006-2018 at Deception and Livingston island, Antarctica. Abstracts of the VII Iberian Conference of the International Permafrost Association, Jaca, Spain, 66.

de Pablo, M.A., de Pablo, C., Prieto, M. 2019b. Testing Permarduino device on extreme and harsh weather conditions in Antarctica. Abstracts of the VII Iberian Conference of the International Permafrost Association, Jaca, Spain, 96.

de Pablo, M.A., Jiménez, J.J., Prieto, M., Ramos, M., Hidalgo, M.A. 2019c. Snow pack properties and thermal behaviour, and their evolution at the Crater Lake CALM site, Deception island, Antarctica. Abstracts of the VII Iberian Conference of the International Permafrost Association, Jaca, Spain, 54.

de Pablo, M.A., Jiménez, J.J., Prieto, M., Ramos, M., Hidalgo, M.A. 2019d. Snow cover effect on active layer thickness and ground surface temperature at Limnopolar Lake CALM site (Byers peninsula, Livingston island), Antarctica. Abstracts of the VII Iberian Conference of the International Permafrost Association, Jaca, Spain, 53.

de Pablo, M.A., de Pablo, C., Ramos, M. 2014. A prototype of an open hardware-based device for active layer and frozen ground monitoring: PERMARDUINO. Book of Abstracts of EUCOP4 - 4th European Conference on Permafrost. 18-21 June 2014, Évora, Portugal, 444.

Gehl, R.J., Rice, C.W. 2007. Emerging technologies for in situ measurement of soil carbon. Climate Change 80, 43-54. https://doi.org/10.1007/s10584-006-9150-2.

Goodrich, L.E. 1982. The influence of snow cover on the ground thermal regime. Canadian Geotechnical Journal 19. 421-432. https://doi.org/10.1007/s10584-006-9150-2.

Guglielmin, M., Evans, C.J.E., Cannone, N. 2008. Active layer thermal regime under different vegetation conditions in permafrost areas. A case study at Signy Island (Maritime Antarctica). Geoderma 144, 73-85. https://doi.org/10.1016/j.geoderma.2007.10.010.

Härer, S., Bernhardt, M., Corripio, J.G., and Schulz, K. 2013. PRACTISE - Photo Rectification and Classification Software (V.1.0). Geoscientific Model Development 6, 837-848.

Hoelzle, M., Haeberli, W., Keller, F, 1993. Application of BTS-measurements for modelling mountain permafrost distribution. Proceedings $6^{\text {th }}$ International Conference on Permafrsost, Vol. 1. 272-277.

Houghton, D.D. 1985. Handbook of applied meteorology. John Willey, New York.

Hrbáček, F. and Uxa, T. 2019 The evolution of a near-surface ground thermal regime and modelled active-layer thickness on James Ross Island, Eastern Antarctic Peninsula, in 2006-2016. Permafrost and Periglacial Processes. https://doi.org/10.1002/ppp.2018.

Hrbáček, F., Láska, K., Engel, Z. 2016a. Effect of snow cover on the active-layer thermal regime - A case study from James Ross Island, Antarctic Peninsula. Permafrost and Periglacial Processes 27, 307-315. https://doi.org/10.1002/ppp.1871.

Hrbáček, F., Oliva, M., Laska, K., Ruiz-Fernández, J., de Pablo, M.A., Vieira, G., Ramos, M., Nývlt, D., 2016b. Active layer thermal regime in two climatically contrasted sites of the Antarctic Peninsula region. Cuadernos de Investigación Geográfica 42 (2), 457-474. https:// doi.org/10.18172/cig.2915.

Hrbáček, F., Vieira, G., Oliva, M., Balks, M., Guglielmin, M., de Pablo, M.A., Molina, A., Ramos, M., Goyanes, G., Meiklejohn, I., Abramov, A., Demidov, N., Fedorov-Davydov, D., Lupachev, A., Rivkina, E., Láska, K., Kňažková, M., Nývlt, D., Raffi, R., Strelin, J., Sone, T., 
Fukui, K., Dolgikh, A., Zazovskaya, E., Mergelov, N., Osokin, N., Miamin, V. 2018. Active layer monitoring in Antarctica: an overview of results from 2006 to 2015. Polar Geography https://doi.org/10.1080/1088937X.2017.1420105.

IPCC, 2013. Climate Change 2013: The Physical Science Basis. In: T.F. Stocker, D. Qin, G.K. Plattner, M. Tignor, S.K. Allen, J. Boschung, A. Nauels, Y. Xia, V. Bex, P.M. Midgley (Eds.), Contribution of Working Group I to the Fifth Assessment Report of the Intergovernmental Panel on Climate Change, Cambridge University Press, Cambridge, United Kingdom and New York, NY, 1535 pp.

IPCC, 2018. Summary for Policymakers. In: V. Masson-Delmotte, P. Zhai, H.O. Pörtner, D. Roberts, J. Skea, P.R. Shukla, A. Pirani, W. Moufouma-Okia, C. Péan, R. Pidcock, S. Connors, J.B.R. Matthews, Y. Chen, X. Zhou, M.I. Gomis, E. Lonnoy, T. Maycock, M. Tignor, and T. Waterfield (Eds.), Global Warming of $1.5^{\circ} \mathrm{C}$. An IPCC Special Report on the impacts of global warming of $1.5^{\circ} \mathrm{C}$ above pre-industrial levels and related global greenhouse gas emission pathways, in the context of strengthening the global response to the threat of climate change, sustainable development, and efforts to eradicate poverty. In Press, available at: https://www.ipcc.ch/

Ives, J.D. 1974. Permafrost. In: J.D. Ives, R.G. Barry (Eds.), Arctic and Alpine Environments. Methuen, London, pp. 159-194.

Jafarov, E.E., Nicolsky, D.J., Romanovsky, V.E., Walsh, J.E., Panda, S.K., Serreze, M.C. 2014. The effect of snow: How to better model ground surface temperatures. Cold Regions Science and Technology 102, 63-77. https://doi.org/10.1016/j.coldregions.2014.02.007.

Jafarov, E.E., Marchenko, S.S., Romanovsky, V.E. 2012. Numerical modeling of permafrost dynamics in Alaska using a high spatial resolution dataset. The Cryosphere, 6, 613-624. https://doi.org/10.5194/tc-6-613-2012.

Jiménez, J.J., Ramos, M., de Pablo, M.A., Vieira, G., Molina, A., 2013. Active layer thermal variability, snow thickness coupled, in the vicinity of the Spanish Antarctic Station Juan Carlos I. In Avances, métodos y técnicas de estudio del periglaciarismo/Avanços, métodos y técnicas para o estudio do periglaciarismo. Publicacions i Edicions de la Universitat de Barcelona, Barcelona, pp. 287-300.

Jiménez, J.J.,Ramos, M., Vieira,G. 2016. El balance energético suelo/aire en las regiones con suelos helados mediatizado por el efecto aislante de la cobertura nival. El caso del Archipiélago de las Islas Shetland del Sur (Antártida). In: Quintas Jornadas de Jóvenes Investigadores de la Universidad de Alcalá. Universidad de Alcalá, Madrid, pp. 23-32.

Jiménez, J.J., Ramos, M. 2019. Estudio de la cobertura nival en la Antártida Marítima mediante imágenes Radar y datos observacionales. In: Séptimas Jornadas de Jóvenes Investigadores de la Universidad de Alcalá. Universidad de Alcalá, Madrid, pp. 237-246.

Jiménez, J.J., de Pablo, M.A., Ramos, M., Sánchez, J.M. 2019a. Metodología de clasificación de superficies innivadas mediante análisis de imágenes fotográficas periódicas en la Antartida Marítima. IPA Ibérico Jaca Proceedings.

Jiménez, J.J., Ramos, M., Vieira, G., Pina, P., de Pablo, M.A. 2019b. Evolución de la cubierta nival estacional en la antartida marítima mediante imágenes Terrasar X. IPA ibérico Jaca Proceedings.

Keller, F. 1992. Automated mapping of mountain permafrost using the program PERMAKART within the geographical information system ARC/INFO. Permafrost and Periglacial Processes 3 (2), 133-138. https://doi.org/10.1002/ppp.3430030210.

Kelley, J.J., Weaver, D.F. 1969. Physical processes at the surface of the arctic tundra. Arctic 22 (4), 425-437. https://doi.org/10.14430/arctic3233.

Laine, V. 2008. Antarctic ice sheet and sea ice regional albedo and temperature change, 1981-2000, from AVHRR Polar Pathfinder data. Remote Sensing of the Environment 112, 646-667. 
Levin, N., Ben-Dor, E., Singer. A. 2005. A Digital Camera as A Tool to Measure Color Indices and Related Properties of Sandy Soils in Semi-Arid Environments. International Journal of Remote Sensing 26 (24), 5475-5492. https://doi.org/10.1080/01431160500099444.

Lewkowicz, A.G. 2008. Evaluation of miniature temperature-loggers to monitor snowpack evolution at mountain permafrost sites, northwestern Canada. Permafrost and Periglacial Processes 19, 323-331. https://doi.org/10.1002/ppp.625.

Louis, L. 2016. Working principle of Arduino and using it as a tool for study and research. International Journal of Control, Automation, Communication and Systems, 1 (2), 21-29.

Lunardini, V.J. 1978. Theory of $\mathrm{n}$-factors and correlation of data. In Proceedings, 3rd International Conference on Permafrost, Edmonton, Alberta, July 10-13, 1978. National Research Council of Canada. Ottawa, ON. 1, pp. 40-46.

Mackiewicz, M.C. 2012. A new approach to quantifying soil temperature responses to changing air temperature and snow cover. Polar Science 6, 226-236. https://doi.org/10.1016/j. polar.2012.06.003.

Maior, C.N. 2019. Caracterización del permafrost y la capa activa en la región de Crater Lake, Isla Decepción, Antártida. BSc Thesis, University of Alcalá, Spain. 60 pp.

Maior, C.N., de Pablo, M.A., Prieto, M., Ramos, M., Vieira, G., Abramov, A. 2019. Thermal evolution of permafrost and active layer at the Crater Lake monitoring site, Deception island, Antarctica. Abstracts of the VII Iberian Conference of the International Permafrost Association, Jaca, Spain, 8.

Malik, M.J., van der Velde, R., Vekerdy, Z., Su, Z. 2012. Assimilation of satellite-observed snow albedo in a land surface model. Journal of Hydrometeorology 13 (3), 1119-1130. https://doi. org/10.1175/JHM-D-11-0125.1.

Marchenko, S., Romanovsky, V.E., Tipenko, G. 2008. Numerical modeling of spatial permafrost dynamics in Alaska. In: In Proceedings of the Eighth International Conference on Permafrost. Willey, Institute of Northern Engineering, University of Alaska, Fairbanks, pp. 190-204.

Marsh, P., Woo, M.K., 1984. Wetting front advance and freezing of meltwater whitin a snow cover. Observations in the Canadian Arctic. Water Resources Research 16, 1853-1864. https://doi. org/10.1029/WR020i012p01853.

Matsuoka, N. 2006. Monitoring periglacial processes: Towards construction of a global network. Geomorphology 80, 20-31. https://doi.org/10.1016/j.geomorph.2005.09.005.

Matsuoka, N., Humlum, O. 2003. Monitoring periglacial processes: new methodology and technology. Permafrost and Periglacial Procceses 14, 299-303. https://doi.org/10.1002/ ppp.461.

Mora, C., Jiménez, J.J., Pina, P., Catalão, J., Vieira, G. 2017. Evaluation of single-band snow-patch mapping using high-resolution microwave remote sensing: An application in the maritime Antarctic. Cryosphere 11 (1), 139-155. https://doi.org/10.5194/tc-11-139-2017.

Mora, C., Vieira, G., Ramos, M. 2013. Evaluation of Envisat ASAR IMP imagery for snow mapping at varying spatial resolution (Deception Island, South Shetlands - Antarctica). Geological Society, London, Special Publications. https://doi.org/10.1144/SP381.19.

Morales, M. 2017. Evolución térmica y del espesor de la capa activa en el CALM Crater Lake de Isla Decepción, Antártida. BSc Thesis, University of Alcalá, Spain. (in Spanish), 38 pp.

Morales, M., de Pablo, M.A. 2017. Relación entre el espesor de la capa active (ALT) y la temperatura del techo del permafrost (TTOP) en CALM-S Crater Lake, Isla Decepción, Antártida. In: J. Ruiz-Fernández, C. García-Hernández, M. Oliva, C. Rodríguez Pérez, D. Gallinar (Eds.), Ambientes periglaciares: avances en su estudio, valoración patrimonial y riesgos asociados Universidad de Oviedo.

NASA (nad). Snow pits procedures. Available in: https://www.nasa.gov/pdf/186123main_ SnowPitProcedures.pdf. 
Navarro, F., Jonsell, U.J., Corcuera, M.I., Martín-Español, A. 2013. Decelerated mass loss of Hurd and Johnsons Glaciers, Livingston Island, Antarctic Peninsula. Journal of Glaciology 59 (213), 115-128. https://doi.org/10.3189/2013joG12j144.

Nelson, F.E., Shiklomanov, N.I., Hinkel, K.M., Christiansen, H.H. 2004. The Circumpolar active layer monitoring (CALM) Workshop and THE CALM II Program. Polar Geography 28 (4), 253-266, https://doi.org/10.1080/789610205.

Nicolsky, D.J., Romanovsky, V.E., Tipenko, G.S. 2007. Using in situ temperature measurements to estimate saturated soil thermal properties by solving a sequence of optimization problems. The Cryosphere 1, 41-58. https://doi.org/10.5194/tc-1-41-2007.

Nicolsky, D., Romanovsky, V., Panteleev, G.G. 2009. Estimation of soil thermal properties using in-situ temperature measurements in the active layer and permafrost, Cold Regions Science and Technology 55, 120-129. https://doi.org/10.1016/j.coldregions .2008.03.003.

Nicolsky, D.J., Romanovsky, V.E., Panda, S.K., Marchenko, S.S., Muskett, R.R. 2017. Applicability of the ecosystem type approach to model permafrost dynamics across the Alaska North Slope, Journal of Geophysical Research Earth Surface 122, 50-75. https://doi. org/10.1002/2016JF003852.

Oliva, M., Hrbacek, F., Ruiz-Fernández, J., de Pablo, M.Á., Vieira, G., Ramos, M., Antoniades, D. 2017a. Active layer dynamics in three topographically distinct lake catchments in Byers Peninsula (Livingston Island, Antarctica). Catena 149, 548-559. https://doi.org/10.1016/j. catena.2016.07.011

Oliva, M., Navarro, F., Hrbáček, F., Hernández, A., Nývlt, D., Pereira, P., Ruiz-Fernández, J., Trigo, R. 2017b. Recent regional climate cooling on the Antarctic Peninsula and associated impacts on the cryosphere. Science of the Total Environment 580, 210-223. https://doi. org/10.1016/j.scitotenv.2016.12.030.

Outcalt, S.I., Nelson, F.E., Hinkel, K.M. 1990. The zero-curtain effect: heat and mass transfer across an isothermal region in freezing soil. Water Resources Research 26 (7), 1509-1516. https://doi.org/10.1029/WR026i007p01509.

Prieto, M., de Pablo, M.A. 2017. PERMARADIO: acceso remoto a datos de una estación antártica para el control térmico del permafrost. Abstracts of the VII Iberian Conference of the International Permafrost Association, Mieres, Spain.

Recondo, C., Corbea-Pérez, A., Peón, J., Pendás, E., Ramos, M., Calleja, J.F., de Pablo, M.A., Fernández, S., Corrales, J.A. 2019. Variability of the air temperature and its comparison with MODIS Land Surface Temperature in the Hurd Peninsula of the Livingston Island, Antarctica, between 2000 and 2016. Under review.

Sancho, L.G., Pintado, A., Navarro, F., Ramos, M., de Pablo, M.A., Blanquer, J.M., Raggio, J., Green, T.G.A. 2017. Recent warming and cooling in the Antarctic Peninsula region has rapid and large effects on lichen vegetation. Scientific Reports 7, 1-8.

Santilli, G., Vendittozzi, C., Cappelletti, C., Battistini, S., Gessini, P. 2018. CubeSat constellations for disaster management in remote areas. Acta Astronautica 145, 11-17. https://doi. org/10.1016/j.actaastro.2017.12.050.

Singh A.K. 2011. Snow Pit. In: V.P. Singh, P. Singh, U.K. Haritashya (Eds.) Encyclopedia of Snow, Ice and Glaciers. Encyclopedia of Earth Sciences Series. Springer, Dordrecht, pp. 10631064. https://doi.org/10.1007/978-90-481-2642-2_679.

Smith, M.W., Riseborough, D.W. 2002. Climate and the limits of permafrost: A zonal analysis. Permafrost and Periglacial Processes 13. 1-15. https://doi.org/10.1002/ppp.410.

Tipenko, G., Marchenko, S., Romanovsky, V., Groshev, V., Sazonova, T. 2004. Spatially distributed model of permafrost dynamics in Alaska, EOS, Transactions of the AGU, 85, Fall Meet. Suppl., Abstract C12A-02. 
Turner, J., Colwell, S.R., Marshall, G.J., Lachlan-Cope, T.A., Carleton, A.M., Jones, P.D., Lagun, V., Reid, P.A., Iagovkina, S. 2005. Antarctic climate change during the last 50 years. International Journal of Climatology 25, 279-294. https://doi.org/10.1002/joc.1130.

Turner, J., Lu, H., White, I., King, J.C., Phillips, T., Hosking, J.S., Bracegirdle, T.J., Marshall, G.J., Mulvaney, R., Deb, P. 2016. Absence of 21st century warming on Antarctic Peninsula consistent with natural variability. Nature 535,411-415. https://doi.org/10.1038/nature18645.

van Wessem, J.M., Ligtenberg, S.R.M., Reijmer, C.H., van de Berg, W.J., van den Broeke, M.R., Barrand, N.E., Thomas, E.R., Turner, J., Wuite, J., Scambos, T.A., van Meijgaard, E., 2016. The modelled surface mass balance of the Antarctic Peninsula at $5.5 \mathrm{~km}$ horizontal resolution. The Cryosphere 10, 271-285. https://doi.org/10.5194/t.c-10-271-2016.

Vasques, G.M., Grunwald, S., Sickman, J.O. 2008. Comparison of multivariate methods for inferential modeling of soil carbon using visible/near-infrared spectra. Geoderma 146, 1425. https://doi.org/10.1016/j.geoderma.2008.04.007.

Venkataraman, G., Singh, G., Kumar, V. 2013. Snow cover area monitoring using multi-temporal TerraSAR-X data. Available at: http:IIsss.terrasar-x.dlr.de/papers_sci_meet_3/poster / LAN0122_Venkataraman.pdf.

Vieira, G., Bockheim, J., Guglielmin, M., Balks, M., Abramov, A.A., Boelhouwers, J., Cannone, N., Ganzert, L., Gilichinsky, D.A., Goryachkin, S., López-Martínez, J., Meiklejohn, I., Raffi, R., Ramos, M., Schaefer, C., Serrano, E., Simas, F., Sletten, R., Wagner, D. 2010. Thermal state of permafrost and active-layer monitoring in the antarctic: Advances during the international polar year 2007-2009. Permafrost and Periglacial Processes 21, 182-197. https://doi.org/10.1002/ppp.685.

Viscarra Rossel, R.A., Behrens, T. 2010. Using data mining to model and interpret soil diffuse reflectance spectra. Geoderma 158, 46-54. https://doi.org/10.1016/j.geoderma.2009.12.025.

Warren, S.G., 1982. Optical properties of snow. Reviews of Gephysics 20 (1), 67-89. https://doi. org/10.1029/RG020i001p00067.

Westermann, S., Langer, M., Boike, J. 2011. Spatial and temporal variations of summer surface temperatures of high-arctic tundra on Svalbard - Implications for MODIS LST based permafrost monitoring. Remote Sensing of Environment 115, 908-922. https://doi. org/10.1016/j.rse.2010.11.018.

Westermann, S., Langer, M., Boike, J. 2012. Systematic bias of average winter-time land surface temperatures inferred from MODIS at a site on Svalbard, Norway. Remote Sensing of Environment 118, 162-167. https://doi.org/10.1016/j.rse.2011.10.025.

Woo, M-K. 2012. Permafrost hydrology. Springer, London, 227 pp.

Zhang, T. 2005. Influence of the seasonal snow cover on the ground thermal regime: an overview. Reviews of Geophysics 43, RG4002. https://doi.org/10.1029/2004RG000157. 